\title{
Dysregulation of miRNAs in bladder cancer: altered expression with aberrant biogenesis procedure
}

\author{
Fan Dong ${ }^{1}$, Tianyuan Xu' ${ }^{2}$, Yifan Shen ${ }^{1}$, Shan Zhong ${ }^{1}$, Shanwen Chen ${ }^{1}$, Qiang Ding ${ }^{1}$ \\ and Zhoujun Shen ${ }^{1}$ \\ ${ }^{1}$ Department of Urology, Fudan Institute of Urology, Huashan Hospital, Fudan University, Shanghai, China \\ ${ }^{2}$ Department of Urology, Ruijin Hospital, School of Medicine, Shanghai Jiaotong University, Shanghai, China \\ Correspondence to: Zhoujun Shen, email: shenzjhuashan@sina.com \\ Keywords: microRNA, bladder cancer, expression profile, biogenesis procedure \\ Received: October 19,2016 Accepted: January 24, $2017 \quad$ Published: February 07, 2017
}

Copyright: Dong et al. This is an open-access article distributed under the terms of the Creative Commons Attribution License (CC-BY), which permits unrestricted use, distribution, and reproduction in any medium, provided the original author and source are credited.

\section{ABSTRACT}

\begin{abstract}
Aberrant expression profiles of miRNAs are widely observed in the clinical tissue specimens and urine samples as well as the blood samples of bladder cancer patients. These profiles are closely related to the pathological features of bladder cancer, such as the tumour stage/grade, metastasis, recurrence and chemo-sensitivity. MiRNA biogenesis forms the basis of miRNA expression and function, and its dysregulation has been shown to be essential for variations in miRNA expression profiles as well as tumourigenesis and cancer progression. In this review, we summarize the up-todate and widely reported miRNAs in bladder cancer that display significantly altered expression. We then compare the miRNA expression profiles among three different sample types (tissue, urine and blood) from patients with bladder cancer. Moreover, for the first time, we outline the dysregulated miRNA biogenesis network in bladder cancer from different levels and analyse its possible relationship with aberrant miRNA expression and the pathological characteristics of the disease.
\end{abstract}

\section{INTRODUCTION}

Urinary bladder cancer $(\mathrm{BCa})$, which ranks number seven on the list of the most common malignancies in male patients, severely impairs public health. The morbidity and mortality of bladder cancer are both the second-highest among all urinary tumours, just after prostate cancer [1]. Although the majority of patients (75\%-85\%) suffer from non-muscle invasive bladder cancer (NMIBC) (pTa-pT1), the recurrence rate following the transurethral resection of bladder tumours (TURBT) can be up to $75 \%$ within 5 years [2], and the disease may invade the muscle layer very quickly. Bladder tumours are not easy to cure due to their high recurrence and metastasis rates, with a five-year survival rate of approximately $57 \%$ [3]. Thus, research on $\mathrm{BCa}$, especially on the mechanisms of carcinogenesis and tumour progression, still need more time to evolve. New discoveries are required to update the diagnostic methods as well as the therapeutic strategies.

MicroRNAs (miRNAs) are a group of highly conserved small non-coding RNAs [4], and they can post-transcriptionally regulate gene expression by directly targeting mRNAs. They are widely involved in the proliferation, differentiation and apoptosis of cells [5]. MiRNAs may work as either oncogenes or tumour suppressors, and they are deeply implicated in the oncogenesis and progression of various carcinomas, including bladder cancer [6-8]. A large number of studies have shown that the miRNA expression profile is significantly changed not only in tumour specimens but also in the urine and blood of bladder cancer patients [9-11]. Dysregulations in miRNA expression are closely related to the development of bladder cancer, such as chemotherapy resistance and a worse prognosis $[12,13]$.

MiRNA biogenesis has been shown to play an important role in bladder cancer. MiRNA biogenesis is a complicated network that starts from the transcription of coding genes and ends up with mature miRNAs targeting mRNAs [14]. Numerous proteins, enzymes and factors are involved in the regulation of miRNA biogenesis, including some key components such as DROSHA/DGCR8 [15] and DICER [16]. Recent research has confirmed that the abnormalities of the miRNA biogenesis pathway may alter the miRNA expression profile and have an impact on the progression of various urinary cancers $[17,18]$. In bladder cancer, the theory above is further verified; that is, impaired miRNA biogenesis can directly induce 
Table 1: Dysregulated miRNAs among different biological samples reported by multiple studies in bladder cancer

\begin{tabular}{|c|c|c|c|c|c|c|c|}
\hline miRNAs & Sample types & Up/Down & References & miRNAs & Sample types & Up/Down & References \\
\hline let-7a & Tissue & $\downarrow$ & {$[9,110]$} & let-7b & Tissue,Urine & $\uparrow, \uparrow^{U}$ & {$[27] /[39] \mathrm{U}$} \\
\hline let-7c & Tissue & $\downarrow$ & {$[9,111-113]$} & $\operatorname{miR}-1$ & Tissue,Urine,Blood & $\downarrow, \downarrow^{\mathrm{U}}, \downarrow^{\mathrm{B}}$ & $\begin{array}{l}{[9,27,28,37,111,112,} \\
114,115] / \\
{[116] \mathrm{T} \& \mathrm{U} /[117] \mathrm{B}}\end{array}$ \\
\hline miR-9 & Tissue & $\uparrow$ & {$[37,118,119]$} & miR-10a & Tissue & $\uparrow$ & {$[27,28,114,120]$} \\
\hline miR-10b & Tissue,Urine & $\uparrow, \uparrow^{U}$ & {$[114,120,121] /[122] \mathrm{U}$} & miR-15a a & Tissue,Urine & $\uparrow, \downarrow^{\text {Ua }}, \uparrow^{\text {Ua }}$ & {$[27] /[39,40] \mathrm{U}$} \\
\hline miR-15b & Urine,Blood & $\downarrow^{\mathrm{U}}, \downarrow^{\mathrm{B}}$ & {$[40] \mathrm{U} /[123] \mathrm{B}$} & $\operatorname{miR}-16$ & Tissue,Urine & $\uparrow, \uparrow^{U}$ & {$[27,124] /[116] \mathrm{T} \& \mathrm{U}$} \\
\hline miR-17-5p & Tissue & $\uparrow$ & {$[9,23,42,125]$} & miR-18a & Tissue, Blood & $\uparrow \uparrow^{\mathrm{B}}$ & {$[9,42] /[10] \mathrm{B}$} \\
\hline $\operatorname{miR}-18 a^{*}$ & Tissue,Urine & $\uparrow, \uparrow^{U}$ & {$[27] /[126] \mathrm{U}$} & miR-19a & Tissue,Blood & $\uparrow, \uparrow^{B}$ & $\begin{array}{l}{\left[\begin{array}{ll}9,27] /[127] \mathrm{B} /[128] \\
\mathrm{T} \& \mathrm{~B}\end{array}\right.} \\
\end{array}$ \\
\hline $\operatorname{miR}-19 b$ & Tissue & $\uparrow$ & {$[9,27]$} & miR-20a & Tissue & $\uparrow$ & {$[9,33,125,129]$} \\
\hline $\operatorname{miR}-21$ & $\begin{array}{l}\text { Tissue,Urine, } \\
\text { Blood }\end{array}$ & $\uparrow, \uparrow^{\mathrm{U}}, \uparrow^{\mathrm{B}}$ & $\begin{array}{l}{[26,27,30,120, \quad 130,} \\
131] / \\
{[39,132] \mathrm{U} /[10] \mathrm{U} \& \mathrm{~B}} \\
\end{array}$ & $\operatorname{miR}-23 b$ & Tissue & $\downarrow$ & {$[109,131,133]$} \\
\hline miR-24-1 & Tissue,Urine & $\downarrow, \downarrow^{\mathrm{U}}$ & {$[40] \mathrm{U} /[134]$} & $\operatorname{miR}-25$ & Tissue,Urine,Blood & $\downarrow, \uparrow^{\mathrm{U}}, \downarrow^{\mathrm{B}}$ & $\begin{array}{l}{[27,28,42] /[126] \mathrm{U} /} \\
{[135] \mathrm{B}}\end{array}$ \\
\hline miR-26a & Tissue & $\downarrow$ & {$[34,35,110,129]$} & miR-26b-5p & Tissue,Blood & $\downarrow, \uparrow^{\mathrm{B}}$ & {$[10] \mathrm{B} /[136]$} \\
\hline $\operatorname{miR}-27 a$ & Urine,Blood & $\downarrow^{\mathrm{U}}, \downarrow^{\mathrm{B}}$ & {$[126] \mathrm{U} /[123,127] \mathrm{B}$} & $\operatorname{miR}-27 b$ & Tissue,Urine & $\downarrow, \downarrow^{\mathrm{U}}$ & {$[40] \mathrm{U} /[109]$} \\
\hline miR-29a & Tissue,Urine & $\downarrow, \downarrow^{\mathrm{U}}$ & {$[42,129] /[10] \mathrm{U}$} & $\operatorname{miR}-29 c$ & Tissue & $\downarrow, \uparrow^{U}$ & \begin{tabular}{|l}
{$[114,137,138] /[122]$} \\
$\mathrm{U}$
\end{tabular} \\
\hline miR-30a & Tissue & $\downarrow, \downarrow^{\mathrm{B}}$ & {$[24,139] /[123] \mathrm{B}$} & $\mathrm{miR}-30 \mathrm{~b} \mathrm{~b}$ & Tissue,Urine & $\downarrow^{\mathrm{b}}, \uparrow^{\mathrm{b}}, \downarrow^{\mathrm{U}}$ & {$[30-32] /[140] \mathrm{U}$} \\
\hline miR-30e-5p & Tissue & $\downarrow$ & {$[110,141]$} & miR-31 & Tissue & $\downarrow$ & {$[30,142,143]$} \\
\hline miR-34a & Tissue & $\downarrow, \downarrow^{\mathrm{B}}$ & {$[76,144] /[145] \mathrm{T} \& \mathrm{~B}$} & miR-92a & UrineBlood & $\uparrow^{\mathrm{U}}, \downarrow^{\mathrm{B}}$ & {$[126] \mathrm{U} /[135,146] \mathrm{B}$} \\
\hline miR-93 & Tissue,Urine & $\uparrow, \uparrow^{U}$ & {$[18,27,42] /[39] \mathrm{U}$} & miR-96 & Tissue,Urine & $\uparrow, \uparrow^{\mathrm{U}}$ & \begin{tabular}{|l}
{$\left[\begin{array}{ll}9, & 125] /[116] \mathrm{T} \& \mathrm{U} / \\
{[147] \mathrm{U}}\end{array}\right.$} \\
\end{tabular} \\
\hline miR-99a & $\begin{array}{l}\text { Tissue,Urine, } \\
\text { Blood } \\
\end{array}$ & $\downarrow, \downarrow^{\mathrm{U}}, \downarrow^{\mathrm{B}}$ & \begin{tabular}{|l}
{$[9,28] /[116] \mathrm{T} \& \mathrm{U}$} \\
{$[140] \mathrm{U} /[117] \mathrm{B}$} \\
\end{tabular} & miR-100 & TissueUrine,Blood & $\downarrow, \downarrow^{\mathrm{U}}, \downarrow^{\mathrm{B}}$ & $\begin{array}{l}{[9,27,28,33] /[40] \mathrm{U} /} \\
{[117,146] \mathrm{B}} \\
\end{array}$ \\
\hline miR-101 & Tissue & $\downarrow$ & {$[114,148,149]$} & miR-106a & Tissue,Blood & $\uparrow, \uparrow^{\mathrm{B}}$ & {$[27] /[150] \mathrm{B}$} \\
\hline $\mathrm{miR}-106 \mathrm{~b}$ & Tissue & $\uparrow$ & {$[27,33,151]$} & miR-122 & \begin{tabular}{|l|} 
Tissue,Blood \\
\end{tabular} & $\downarrow, \downarrow^{\mathrm{B}}$ & {$[127] \mathrm{B} /[152]$} \\
\hline miR-124 & Tissue & $\downarrow$ & {$[153,154]$} & miR-125a & Tissue,Urine & $\downarrow, \downarrow^{\mathrm{U}}$ & \begin{tabular}{|l}
$\begin{array}{l}9,24, \\
125] /[155] \mathrm{U}\end{array}$ \\
\end{tabular} \\
\hline $\operatorname{miR}-125 b$ & Tissue,Urine & $\downarrow, \downarrow^{\mathrm{U}}$ & $\begin{array}{l}{[9,24,27,28,33,42,} \\
125] / \\
{[116] \mathrm{T} \& \mathrm{U} /[126,155] \mathrm{U}}\end{array}$ & miR-126 & Tissue,Urine & $\downarrow, \uparrow^{U}$ & $\underset{\mathrm{U}}{[42,131] /[155,156]}$ \\
\hline miR-127-3p & Tissue & $\downarrow$ & {$[27,112,141]$} & miR-130a & Tissue,Blood & $\downarrow, \uparrow^{\mathrm{B}}$ & {$[127] \mathrm{B} /[33]$} \\
\hline $\operatorname{miR}-130 \mathrm{~b}$ & Tissue & $\uparrow$ & {$[27,29,33,51]$} & miR-133a & Tissue,Urine & $\downarrow, \downarrow^{\mathrm{U}}$ & $\begin{array}{l}{[9,27,28,37,111] /} \\
{[116] \mathrm{T} \& \mathrm{U}}\end{array}$ \\
\hline $\operatorname{miR}-133 b$ & Tissue,Urine & $\downarrow, \downarrow^{\mathrm{U}}$ & \begin{tabular}{|l}
{$[9,28,37,111,115] /$} \\
{$[116] \mathrm{T} \& U$}
\end{tabular} & miR-135b & Tissue,Urine & $\uparrow, \uparrow^{U}$ & {$[27] /[40] \mathrm{U}$} \\
\hline miR-138 c & Tissue & $\uparrow^{\mathrm{c}}, \downarrow^{\mathrm{c}}$ & {$[27,37,38]$} & miR-139-5p & Tissue, Blood & $\downarrow, \uparrow^{\mathrm{B}}$ & \begin{tabular}{|l}
$27,33,111,157] /$ \\
{$[10] \mathrm{B}$}
\end{tabular} \\
\hline miR-140-3p & Tissue & $\downarrow$ & {$[111,141]$} & miR-141 & Tissue,Urine & $\uparrow, \downarrow^{\mathrm{U}}$ & {$[9,27,28,33] /[41] \mathrm{U}$} \\
\hline $\operatorname{miR}-142-3 p$ & Urine,,Blood & $\downarrow^{\mathrm{U}}, \uparrow^{\mathrm{B}}$ & {$[126] \mathrm{U} /[150] \mathrm{B}$} & miR-143 & Tissue,Urine,Blood & $\downarrow, \downarrow^{\mathrm{U}}, \downarrow^{\mathrm{B}}$ & $\begin{array}{l}{[27,28,37, \quad 42,114,} \\
125,131,158, \quad 159] / \\
{[116] \mathrm{T} \& \mathrm{U} /[126] \mathrm{U} /} \\
{[146] \mathrm{B}}\end{array}$ \\
\hline $\operatorname{miR}-144-5 p$ & Tissue,Blood & $\downarrow, \uparrow^{\mathrm{B}}$ & {$[10] \mathrm{B} /[160]$} & miR-145 & Tissue,Urine & $\downarrow, \downarrow^{\mathrm{U}}$ & $\begin{array}{l}{[9,24,27,28,37,42,} \\
114,125,158,159] / \\
{[161,162] \mathrm{U}}\end{array}$ \\
\hline $\begin{array}{l}\operatorname{miR}-146 a- \\
5 p\end{array}$ & Urine,Blood & $\uparrow^{\mathrm{U}}, \downarrow^{\mathrm{B}}$ & {$[127] \mathrm{B} /[163] \mathrm{U}$} & miR-148a & Tissue,Urine & $\downarrow, \downarrow^{\mathrm{U}}$ & {$[126] \mathrm{U} /[164]$} \\
\hline miR-149 & Tissue,Urine & $\uparrow, \uparrow^{U}$ & {$[27] /[126] \mathrm{U}$} & miR-150 & Tissue & $\downarrow$ & {$[24,42]$} \\
\hline miR-152 & $\begin{array}{l}\text { Tissue,Urine, } \\
\text { Blood } \\
\end{array}$ & $\downarrow, \downarrow^{\mathrm{U}}, \uparrow^{\mathrm{B}}$ & {$[24,112] /[74] \mathrm{U} /[123] \mathrm{B}$} & $\operatorname{miR}-155 \mathrm{~d}$ & Tissue,Urine & $\uparrow, \uparrow^{\mathrm{Ud}}, \downarrow^{\mathrm{Ud}}$ & \begin{tabular}{|l}
{$[131,165] /[41,166]$} \\
\end{tabular} \\
\hline miR-182 & Tissue,Urine & $\uparrow, \uparrow^{U}$ & {$[9,27,37,114] /[156] \mathrm{U}$} & miR-182-5p & Tissue & $\uparrow$ & {$[115,167]$} \\
\hline miR-183 & Tissue,Urine & $\uparrow, \uparrow^{U}$ & $\begin{array}{ll}{[9, \quad 114,} & 125] /[116] \\
\mathrm{T} \& \mathrm{U} / & \\
{[147] \mathrm{U}} & \\
\end{array}$ & $\operatorname{miR}-186$ & Tissue & $\downarrow$ & {$[111,168]$} \\
\hline miR-187 & Tissue,Urine & $\uparrow, \uparrow^{\mathrm{U}}$ & {$[27] /[126] \mathrm{U}$} & miR-192 & Urine,Blood & $\downarrow^{\mathrm{U}}, \uparrow^{\mathrm{B}}$ & {$[10] \mathrm{B} /[41] \mathrm{U}$} \\
\hline miR-194 & Tissue,Blood & $\downarrow, \downarrow^{\mathrm{B}}$ & {$[117] \mathrm{B} /[169]$} & miR-195 & Tissue & $\downarrow$ & {$[9,24,170]$} \\
\hline
\end{tabular}




\begin{tabular}{|c|c|c|c|c|c|c|c|}
\hline miR-196a & Tissue & $\uparrow$ & {$[37,114]$} & $\begin{array}{l}\operatorname{miR}-199 a- \\
3 p\end{array}$ & Tissue & $\downarrow$ & {$[27,28,33,112]$} \\
\hline $\begin{array}{l}\operatorname{miR}-199 a- \\
5 p\end{array}$ & Tissue & $\downarrow$ & {$[27,28,112]$} & miR-199b & Tissue & $\downarrow$ & {$[37,42]$} \\
\hline miR-200a & Tissue,Urine & $\uparrow, \downarrow^{U}$ & $\begin{array}{l}{[9,27,28,33,42,120] /} \\
{[41,161] \mathrm{U}} \\
\end{array}$ & miR-200b & Tissue,Urine,Blood & $\uparrow, \downarrow^{U}, \uparrow^{\mathrm{B}}$ & $\begin{array}{l}{[9,27,28,37] /[135]} \\
\mathrm{B} /[41] \mathrm{U}\end{array}$ \\
\hline $\begin{array}{l}\operatorname{miR}-200 b- \\
3 \mathrm{p}\end{array}$ & Tissue,Urine & $\uparrow, \uparrow^{U}$ & $\begin{array}{l}{[9,27,113,141] /[132]} \\
\text { U }\end{array}$ & \begin{tabular}{|l}
$\mathrm{miR}-200 \mathrm{~b}-$ \\
$5 \mathrm{p}$
\end{tabular} & Tissue & $\uparrow$ & {$[27,28,141]$} \\
\hline $\operatorname{miR}-200 \mathrm{c}$ & Tissue,Urine & $\uparrow, \downarrow^{U}$ & $\begin{array}{l}{[9,27,28,31,39,42] /} \\
{[41] \mathrm{U}}\end{array}$ & $\begin{array}{l}\text { miR-200c- } \\
3 \mathrm{p}\end{array}$ & Tissue,Urine & $\uparrow, \uparrow^{U}$ & {$[27] /[132] \mathrm{U}$} \\
\hline miR-203 & Tissue,Urine & $\uparrow, \downarrow^{U}$ & {$[27,114] /[40] \mathrm{U}$} & miR-204 & Tissue,Urine & $\downarrow, \downarrow^{U}$ & $\begin{array}{l}{[27,37,111] /[126,} \\
140] \mathrm{U}\end{array}$ \\
\hline miR-205 & Tissue,Blood & $\uparrow, \uparrow^{\mathrm{B}}$ & $\begin{array}{l}{\left[\begin{array}{llll}27, & 33, & 120, & 130] \\
{[171] \mathrm{B}} & \end{array}\right.} \\
\end{array}$ & miR-205-5p & Tissue,Urine & $\uparrow, \uparrow^{U}$ & {$[27] /[132] \mathrm{U}$} \\
\hline $\operatorname{miR}-210$ & $\begin{array}{l}\text { Tissue,Urine, } \\
\text { Blood }\end{array}$ & $\uparrow, \uparrow^{\mathrm{U}}, \uparrow^{\mathrm{B}}$ & {$[27,42] /[122] \mathrm{U} /[172] \mathrm{B}$} & $\operatorname{miR}-214$ & Tissue,Urine & $\downarrow, \downarrow^{U}$ & {$[27,33,111] /[173] \mathrm{U}$} \\
\hline miR-218 & Tissue & $\downarrow$ & {$[111,120,174,175]$} & miR-221 & Tissue & $\downarrow$ & {$[28,42]$} \\
\hline miR-222 e & Tissue,Urine & $\downarrow^{\mathfrak{e},}, \uparrow^{\mathfrak{e}}, \cup^{\cup}$ & {$[10] \mathrm{U} /[33-36]$} & miR-223 & Tissue & $\downarrow$ & {$[24,112]$} \\
\hline miR-224 & Tissue & $\uparrow$ & {$[27,114,159]$} & miR-301a & Tissue & $\uparrow$ & {$[27,29]$} \\
\hline miR-301b & Tissue & $\uparrow$ & {$[27,29]$} & miR-320a & Tissue,Blood & $\downarrow, \downarrow^{\mathrm{B}}$ & {$[127] \mathrm{B} /[176]$} \\
\hline miR-328 & Tissue,Urine & $\downarrow, \downarrow^{\mathrm{U}}$ & {$[27] /[40] \mathrm{U}$} & miR-338-3p & Tissue,Urine & $\downarrow, \downarrow^{U}$ & {$[27] /[126] \mathrm{U}$} \\
\hline miR-342-3p & Urine,Blood & $\downarrow^{\mathrm{U}}, \uparrow^{\mathrm{B}}$ & {$[10] \mathrm{U} \& \mathrm{~B}$} & miR-362-5p & Tissue,Blood & $\uparrow, \uparrow^{\mathrm{B}}$ & {$[27] /[127] \mathrm{B}$} \\
\hline miR-370 & Tissue & $\downarrow$ & {$[111,177]$} & miR-374a & Blood & $\uparrow^{\mathrm{B}}$ & {$[10,150] \mathrm{B}$} \\
\hline miR-423-5p & Tissue,Blood & $\uparrow, \downarrow^{\mathrm{B}}$ & {$[27] /[127] \mathrm{B}$} & miR-424 & Tissue,Urine & $\downarrow, \downarrow^{\mathrm{U}}$ & {$[126] \mathrm{U} /[178]$} \\
\hline miR-429 & Tissue,Urine & $\uparrow, \downarrow^{U}$ & {$[9,27] /[41] \mathrm{U}$} & miR-451 & Tissue & $\downarrow$ & {$[37,179]$} \\
\hline miR-483-5p & Tissue,Urine & $\uparrow, \uparrow^{U}$ & {$[27] /[10] \mathrm{U}$} & miR-490-3p & Tissue & $\downarrow$ & {$[9,27,112]$} \\
\hline miR-490-5p & Tissue & $\downarrow$ & {$[9,27,115,180,181]$} & miR-497 & Tissue,Blood & $\downarrow, \downarrow^{\mathrm{B}}$ & {$[27,182] /[117] \mathrm{B}$} \\
\hline miR-505 & Tissue,Blood & $\uparrow, \uparrow^{\mathrm{B}}$ & {$[27] /[117] \mathrm{B}$} & miR-574-3p & Tissue,Blood & $\downarrow, \uparrow^{\mathrm{B}}$ & {$[111,183] /[10,127] \mathrm{B}$} \\
\hline miR-625-3p & Tissue,Blood & $\uparrow, \uparrow^{\mathrm{B}}$ & {$[27] /[10] \mathrm{B}$} & miR-629-3p & Tissue,Blood & $\uparrow, \uparrow^{\mathrm{B}}$ & {$[27] /[10] \mathrm{B}$} \\
\hline miR-671-3p & Tissue,Blood & $\uparrow, \uparrow^{\mathrm{B}}$ & {$[27] /[10] \mathrm{B}$} & \begin{tabular}{|l|}
$\mathrm{miR}-708$ \\
\end{tabular} & Tissue & $\uparrow$ & {$[7,27,28]$} \\
\hline $\begin{array}{l}\operatorname{miR}-1207- \\
5 p\end{array}$ & Tissue,Urine & $\downarrow, \downarrow^{U}$ & {$[116] \mathrm{T} \& U$} & $\begin{array}{l}\text { miR-1224- } \\
3 \mathrm{p}\end{array}$ & Tissue,Urine & $\downarrow, \downarrow^{U}$ & {$[40] \mathrm{U} /[74] \mathrm{T} \& \mathrm{U}$} \\
\hline
\end{tabular}

Researches are based on ${ }^{\mathrm{T}}$ Tissue, ${ }^{\mathrm{U}}$ Urine, ${ }^{\mathrm{B}}$ Blood, ${ }^{\mathrm{T} \& \mathrm{U}}$ both Tissue and Urine, ${ }^{\mathrm{T} \& \mathrm{~B}}$ both Tissue and Blood, ${ }^{\mathrm{U} \& \mathrm{~B}}$ both Urine and Blood.

$\uparrow$, Upregulated; $\downarrow$, Downregulated; $\uparrow$ or $\downarrow$ without superscript are variations in bladder cancer tissue.

a: MiR15a is upregulated in urine samples according to ref.39 while ref.40 shows its downregulation;

b: MiR-30b is shown to increase in ref.31-32 and decrease in ref.30,140 (urine sample);

c: MiR-138 is upregulated according to ref.38.That result is in contradiction to the results of ref.27 and ref.37;

d: The level of miR-155 increases in urine supernatant meanwhile decreases in urine sediment(ref.41).

e: Over-expression of miRNA-222 is reported in ref.34-35 which contradicts the results of downregulation in the rest references;

the dysregulation and malfunction of different miRNAs, which may contribute to the clinical progression of bladder cancer $[19,20]$.

In this review, we summarize the current studies on changes in miRNA expression in bladder tumour tissues and urine samples as well as blood collected from patients, and we analyse the aberrantly regulated biogenesis network of BCa-related miRNAs from different angles. We deeply discuss their dysregulations in terms of coding genes, primary transcript processing, pre-miRNA maturation, the miRNA-mRNA binding process and the core components in miRNA biogenesis machinery. In this way, we reveal that an impaired biogenesis network in bladder cancer may lead to wide changes in miRNAs and eventually induce carcinogenesis and the development of BCa.

\section{BIOGENESIS PROCEDURE OF MIRNAS}

The biogenesis pathway of miRNAs begins with the transcription of coding genes by RNA polymerase II (Figure 1). After the primary transcript (pri-miRNA) is generated, the pri-miRNA is then processed into a short precursor miRNA (pre-miRNA). This step is performed by Microprocessor, which contains an RNAse II enzyme (DROSHA) and DiGeorge syndrome critical region 8 (DGCR8) [15]. Pre-miRNA is next pumped out of the nucleus by XPO5 (Exportin 5) with the help of RanGTP. The RNAse III enzyme DICER, which is stored in the cytoplasm, will then cleave the pre-miRNA and generate a miRNA duplex. The guide strand of mature miRNA is installed in the miRNA-induced silencing complex (miRISC) and leads to binding with the miRNA binding 
site located in the 3'UTR of target mRNA. Afterwards, the translation of the target mRNA is suppressed and the corresponding gene is silenced. Considering that the mature miRNA would not work if there was any disorder in the miRNA-mRNA binding, we naturally count the step of "miRNA-mRNA binding" as the very last step of the entire miRNA biogenesis pathway, in accordance with previous studies $[11,21]$. For further information about the miRNA biogenesis pathway, please refer to ref. 22 [22].

\section{SIGNIFICANT EXPRESSION CHANGES IN THE MIRNAS OF BLADDER CANCER}

Hundreds of miRNAs are found to be aberrantly expressed in bladder cancer. In 2007, Gottardo et al. first reported on a set of miRNAs, including miR-223, miR26b, miR-221, miR-103-1, miR-185, miR-23b, miR-203, miR-17-5p, miR-23a, and miR-205, that are dysregulated in bladder cancer. They analysed the involvement of these
miRNAs in the development of the disease [23]. Since then, the disorders of the miRNA expression profile have been revealed gradually. A part of those changed miRNAs is characterized by downregulation while the other part remains over-expressed, compared with normal tissues. The role that a certain miRNA plays in bladder cancer may be reflected by its variation. For example, Ichimi screens fourteen BCas, five normal bladder urothelia samples and three $\mathrm{BC}$ cell lines to find that the expression levels of 19 out of 156 miRNAs decreased, and a subset of 4 miRNAs (miR-30-3p, miR-133a, miR-195 and miR199a*), which usually act as tumour suppressors, are then validated as being downregulated in tumours [24]. By contrast, some other miRNAs such as miR-200c and miR21 are obviously over-expressed in clinical BCa tissues and may have a function in promoting the development of bladder cancer [25, 26]. Numerous investigations using different types of biological samples (clinical tissue specimens, body fluids, bladder cancer cell lines, etc.) portray the general expression profile of miRNAs in the

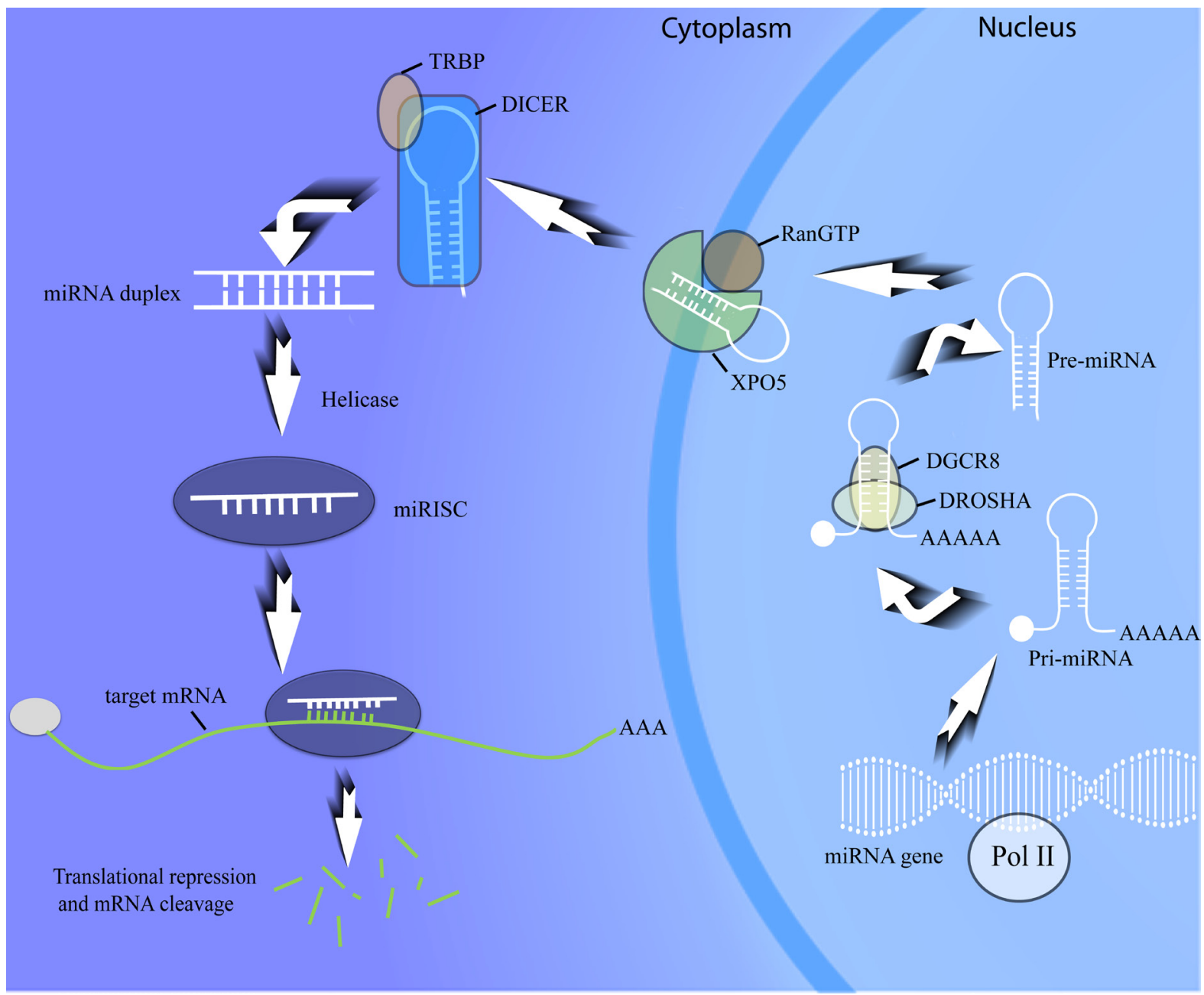

Figure 1: MiRNA biogenesis procedure. The whole biological process basically includes coding gene transcription, pri-miRNA cleavage, pre-miRNA maturation, miRNA-mRNA binding and target mRNA degeneration. miRISC, miRNA-induced silencing complex; TRBP, transactivation-responsive RNA-binding protein. 
Table 2: Common transcription factors regulating miRNA gene transcription in bladder cancer

\begin{tabular}{|c|c|c|c|c|}
\hline Transcription factors & Regulated miRNAs & TFs binding sites & MiRNA functions & References \\
\hline HIF-1 $\alpha$ & miR-145 & MiR-145 promoter & Promoting apoptosis & {$[184]$} \\
\hline Snail-1 & miR-21, miR-29 & Unclear & Promoting metastasis & {$[53]$} \\
\hline p53 & miR-200 family & 5' promoters of the miRNAs & $\begin{array}{lcc}\text { Inhibiting } & \text { EMT } & \text { via } \\
\text { decreasing } & \text { ZEB1/2 }\end{array}$ & {$[185]$} \\
\hline$N F-\kappa B$ & miR-130b & MiR-130b promoter & $\begin{array}{l}\text { Promoting cell proliferation, } \\
\text { invasion and migration }\end{array}$ & {$[51]$} \\
\hline TWIST1 & miR-200 family, miR205 & MiR-200 and miR-205 promoters & \begin{tabular}{|lcr}
$\begin{array}{l}\text { Inhibiting } \\
\text { decreasing }\end{array}$ & EEBT & via \\
\end{tabular} & {$[186]$} \\
\hline PTEN & miR-21,miR-19a, miR-25 & MiRNAs promoters & Oncogenic microRNAs & {$[187]$} \\
\hline p63 $\Delta \mathrm{Np} 63 \alpha$ & miR-205 & $\begin{array}{l}\text { Highly conserved regulatory } \\
\text { region upstream of the miR-205 } \\
\text { start site }\end{array}$ & $\begin{array}{lrl}\text { Inhibiting } & \text { EMT } & \text { via } \\
\text { decreasing } & \text { ZEB1/2 }\end{array}$ & {$[65]$} \\
\hline VHL & $\operatorname{miR}-210$ & Unclear & $\begin{array}{l}\text { Promoting cell growth and } \\
\text { migration }\end{array}$ & {$[187,188]$} \\
\hline
\end{tabular}

TFs, transcription factors; HIF-1 $\alpha$, Hypoxia-inducible factor $1 \alpha$; Snail-1, zinc finger protein SNAI1; $\Delta$ Np63 $\alpha$, p63 isoform protein; VHL, von Hippel-Lindau tumor suppressor; EMT, Epithelial-mesenchymal transition.

context of bladder cancer $[9,10,24]$. To have an insightful understanding of this field, a global review on the current literature about the dysregulations of miRNAs in bladder cancer is undertaken in this manuscript. Literature searches in PubMed for the MESH terms "bladder cancer" and "miRNA" retrieved 473 manuscripts between the years 2006 and 2017. The primary articles and their relevant references were both reviewed. We further summarize the findings on the miRNAs that are widely reported (at least in 2 manuscripts) to be aberrantly expressed in the following three types of biological samples: BCa tissue, urine and blood (Table 1). Studies that focus on either general miRNA expression changes or changes in a specific miRNA are all included in this review. MiRNAs that are reported to be dysregulated only by a single paper or in research that was only based on $\mathrm{BCa}$ cell lines are not counted.

Until the present, miRNA changes in bladder tumour tissues have been the most widely reported among 3 types of biological samples. Out of 118 miRNAs listed in Table 1, 111 (94.06\%) have been shown to be dysregulated in clinical specimens, among which 57 $(51.35 \%)$ are decreased or silenced, including miR-100, the miR-125 family, the miR-133 family, miR-143 and miR-145 [9, 27, 28]; and 51 (45.95\%) miRNAs are overexpressed, such as the miR200 family (miR-200a/b/c) and the miR-130 family (miR-130b, miR-301a and miR301b) [9, 27-29] (Table 1). The variation trends in five miRNAs have been the subjects to contradictory reports [27, 30-41]. It is not hard to see that the variations in the miRNA expression levels are not exactly the same in terms of biological sample types. The tissue and urine samples share the most members ( 37 miRNAs) that have the same variation trends. Twenty-one miRNAs are congruously downregulated in both tissues and urine samples (Figure 2A) while sixteen are over-expressed (Figure 2B). Compared to the studies based on tissues and urine samples, few studies have focused on the variance between urine miRNAs and circulating miRNAs. It is noteworthy that miR-1, miR-99a, miR-100 and miR-143 (Figure 2A) are similarly silenced in all three types of biological samples compared to the normal urothelia and body fluids of healthy people. However, miRNA-21 together with miR-210 are uniformly over-expressed (Figure 2B) in three types of samples. Out of all the miRNAs that are listed in Table 1, miR-30b, miR-222, miR-138, miR15a and miR155 were not chosen to be presented in Figure 2 due to the inconsistency among different studies.

Interestingly, apart from the miRNAs that share the same variation trends in different types of samples, a large number of BCa-related miRNAs show disparate changes in different sample types. For example, miR-342$3 p$ is found to be upregulated in blood but downregulated in the patients' urine [10]. Similarly, miR-200c is widely reported to be over-expressed in tumour tissues [9, 28, 42], while it is expressed to a lesser degree in the urine samples [41]. Since most research on bladder cancer is based on tissue samples, these differences suggest that urine or circulating miRNAs may be disparately expressed, and they may work through totally different mechanisms compared to tissue miRNAs. More research is needed to find the different expression profiles and working mechanisms of urine miRNAs as well as circulating miRNAs in patients with bladder cancer and to identify a certain miRNA or a series of miRNAs, if possible, as non-invasive biomarkers for the screening and diagnosis of this disease.

\section{ABERRATION IN THE MIRNA BIOGENESIS PROCEDURE IN BLADDER CANCER}

Since the expression process of each miRNA should go through the entire miRNA biogenesis pathway, it is easy to deduce that the impaired miRNA biogenesis 
and regulation procedure plays a vital role in the abovementioned aberration and malfunction of miRNAs in bladder cancer [14]. Previous studies have shown that in bladder cancer, various factors can interfere with multiple levels of miRNA biogenesis. By reviewing the updated literature in this area, we are the first to give a comprehensive outline about how the aberrance of miRNA biogenesis results in the dysregulation of miRNAs in bladder cancer, which is classified by the different steps and molecules in the miRNAs biogenesis pathway. We also gather evidence to show that the disorders of both miRNA expressions and the biogenesis pathway are associated with bladder carcinogenesis as well as tumour progression.
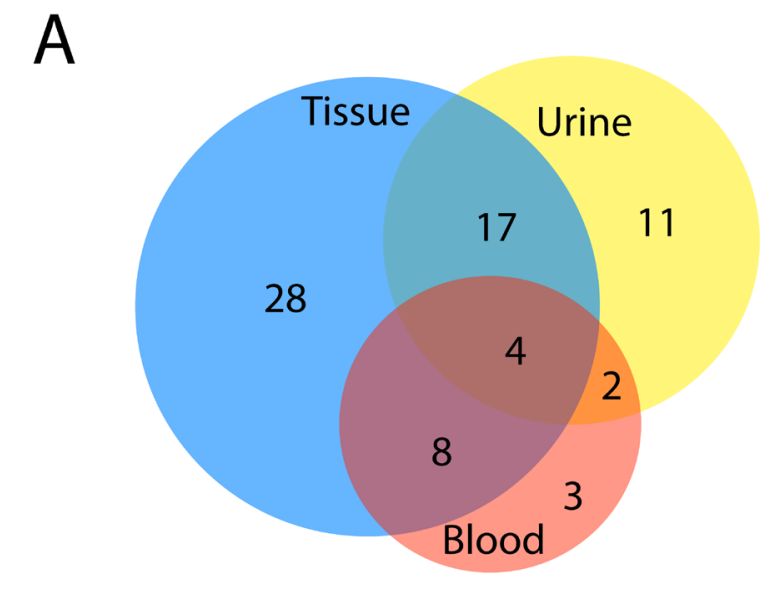

\section{Malfunctions of miRNA coding genes related to bladder cancer}

The biogenesis pathway of BCa-related miRNAs initiates with the transcription of miRNA coding genes. The aberrations at the genetic/chromosomal level would therefore become the very first factor that can alter miRNA expressions. The miRNA coding genes could be impaired by either genetic variations or epigenetic modifications, or they could be influenced by transcription factors and host genes.

\section{Genetic variations}

The single-nucleotide polymorphism (SNP) is a rather common type of genetic variation in cancer. The

$\begin{array}{lllll}\text { a } & & \text { b } & \text { C } & \text { d } \\ \text { T\&U(21) } & & \text { T\&B(12) } & \text { U\&B(6) } & \text { T\&U\&B(4) } \\ \text { miR-1 } & \text { miR-145 } & \text { miR-1 } & \text { miR-1 } & \text { miR-1 } \\ \text { miR-24-1 } & \text { miR-148a } & \text { miR-25 } & \text { miR-27a } & \text { miR-99a } \\ \text { miR-27b } & \text { miR-152 } & \text { miR-30a } & \text { miR-99a } & \text { miR-100 } \\ \text { miR-29a } & \text { miR-204 } & \text { miR-34a } & \text { miR-100 } & \text { miR-143 } \\ \text { miR-99a } & \text { miR-214 } & \text { miR-99a } & \text { miR-143 } & \\ \text { miR-100 } & \text { miR-328 } & \text { miR-100 } & \text { miR-156 } & \\ \text { miR-125a miR-338-3p } & \text { miR-122 } & & \\ \text { miR-125b miR-424 } & \text { miR-143 } & & \\ \text { miR-133a miR-1207-5p } & \text { miR-152 } & & \\ \text { miR-133b miR-1224-3p } & \text { miR-194 } & & \\ \text { miR-143 } & \text { miR-320a } & & \\ & & m i R-497 & \end{array}$

\section{Downregulation}

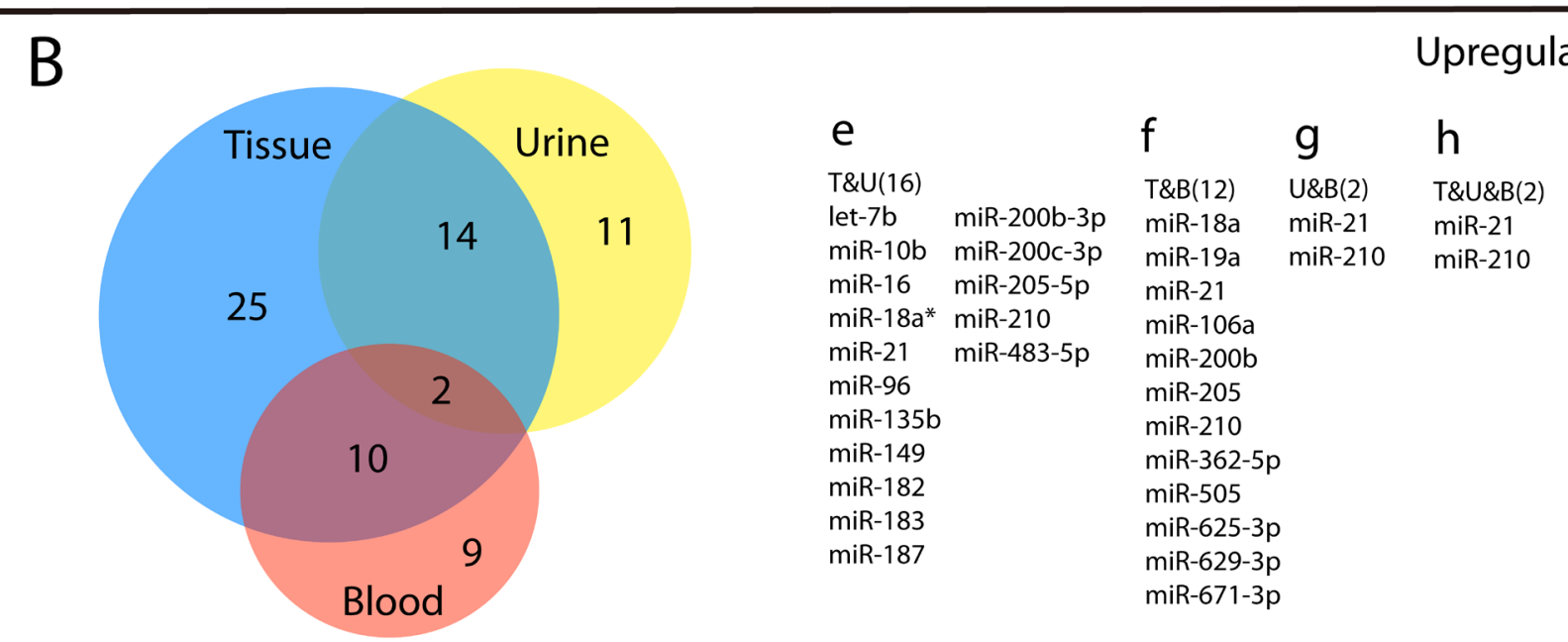

Figure 2: Venn diagram of multiple reported miRNAs in three biological samples. 73 miRNAs are downregulated(A) and 71 are overexpressed(B). Differences of the expression exists among clinical bladder tumor tissues (blue circle), urine samples (yellow circle) and blood (red circle). 21, 12 and 6 miRNAs decrease respectively in subgroups of "Tissue and Urine" (a), "Tissue and Blood" (b) and "Urine and Blood" (c), and 16 (e), 12 (f) and 2 (g) miRNAs are correspondingly over-expressed. The overlapping part of three circles represents miR-1, miR-99a, miR-100 and miR-143 in A, and miR-21 along with miR-210 in B. T\&U, Tissue and Urine; T\&B, Tissue and Blood; U\&B, Urine and Blood; T\&U\&B, Tissue and Urine and Blood. 
SNPs in miRNA coding genes have been validated to directly alter the transcription and maturation of miRNAs [43], and they may be associated with the cancer risk and prognosis [44]. A study that was performed by Wang et al. reveals that the SNP rs2910164 in the miR-146a gene is strongly related to the biological characteristics of bladder cancer, and the rs2910164 C allele, markedly enhances the expression level of miR-146a (a tumour suppressor) in bladder cancer cells compared to the $\mathrm{G}$ version and therefore inhibits cell proliferation. An additional study shows that patients carrying allele $\mathrm{C}$ are endowed with a significantly decreased bladder cancer risk (a 20\% decrease compared to the $\mathrm{G}$ allele) as well as a reduced risk of recurrence [45]. Analogously, a SNP rs11671784 $\mathrm{G} / \mathrm{A}$ variation in the miR-27a gene decreases the miR-27a level and reduces the chemo-sensitivity of bladder cancer [46].
Remarkably, other types of genetic variations, such as gene deletions or point mutations, have also been shown to impact miRNA transcription and then lead to the dysregulation of miRNA expression, which may be associated with the clinical processes of various cancers $[47,48]$. In bladder cancer, Veerla et al. report that miR31 , which is located in $9 \mathrm{p} 21$, is found to be homozygously deleted in patients, and this gene deletion may be related to the downregulation of its expression [49]. To summarize, the gene variations of a certain miRNA may not only alter the expression level of itself but will also be of great significance to the biological features of bladder cancer, such as tumour progression, metastasis, recurrence and chemo-resistance. We have noted that in comparison to the large number of studies based on SNPs, research on other types of genetic variations in $\mathrm{BCa}$ such as gene deletions or point mutations have not been widely

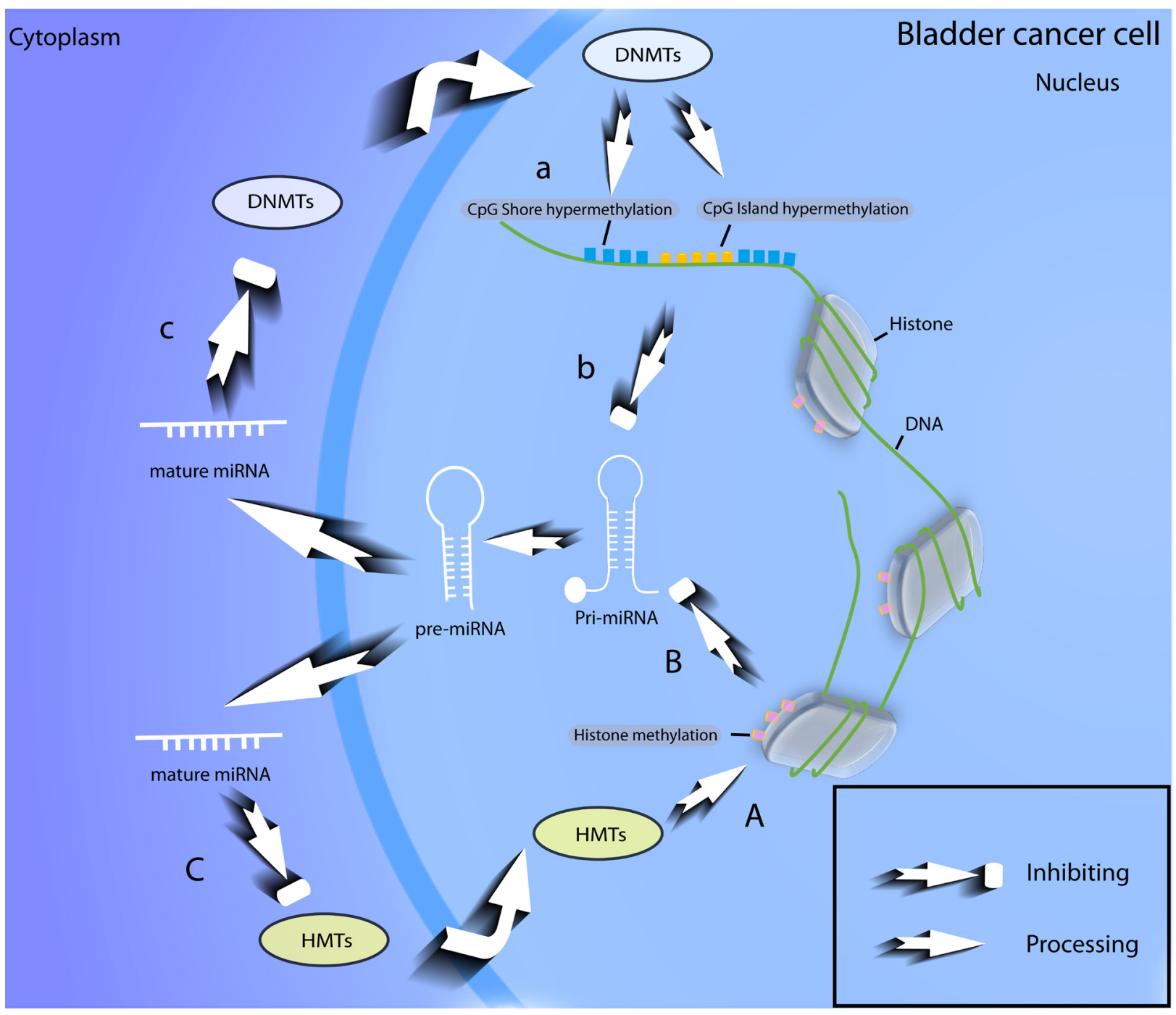

Figure 3: Feedback loop of epigenetic modifications of miRNAs in BCa. With the help of DNMTs and HMTs, miRNA coding genes (a) and related histones (A) can be modified epigenetically, thus anti-cancer miRNAs in urothelial cells are silenced (b, B); Some miRNAs can in turn suppress the expression level of DNMTs (c) and HMTs (C). DNMTs, DNA methyltransferases; HMTs, histone methyltransfereases. 
Table 3: Epigenetic modifications of miRNAs in bladder cancer

\begin{tabular}{|c|c|c|c|c|c|c|c|c|}
\hline MiRNAs & Epigenetic modifications & Location & Targets & $\begin{array}{l}\text { MiRNA } \\
\text { functions }\end{array}$ & $\uparrow / \downarrow$ & $\begin{array}{l}\text { Clinical } \\
\text { significances }\end{array}$ & Sample types & References \\
\hline $\operatorname{miR}-9-3$ & CGI hypermethylation, HM & $15 q 26.1$ & - & $\begin{array}{l}\text { Tumor } \\
\text { suppressor }\end{array}$ & $\downarrow$ & $\begin{array}{l}\text { Potential } \\
\text { biomarker }\end{array}$ & $\begin{array}{l}\text { Tissue, Urine, } \\
\text { Cell lines }\end{array}$ & {$[20,74]$} \\
\hline $\operatorname{miR}-137$ & CGI hypermethylation, HM & $1 \mathrm{p} 21.3$ & PAQR3 & $\begin{array}{l}\text { Tumor } \\
\text { suppressor }\end{array}$ & $\downarrow$ & $\begin{array}{l}\text { Potential } \\
\text { biomarker }\end{array}$ & $\begin{array}{l}\text { Tissue, Urine, } \\
\text { Cell lines }\end{array}$ & {$[20,58]$} \\
\hline miR-124-2 & CGI hypermethylation, HM & $8 \mathrm{q} 12.3$ & UHRF1 & $\begin{array}{l}\text { Tumor } \\
\text { suppressor }\end{array}$ & $\downarrow$ & $\begin{array}{l}\text { Potential } \\
\text { biomarker }\end{array}$ & $\begin{array}{l}\text { Tissue, Urine, } \\
\text { Cell lines }\end{array}$ & {$[20,153]$} \\
\hline $\operatorname{miR} 124-3$ & CGI hypermethylation, HM & $20 \mathrm{q} 13.33$ & UHRF1 & $\begin{array}{l}\text { Tumor } \\
\text { suppressor }\end{array}$ & $\downarrow$ & $\begin{array}{l}\text { Potential } \\
\text { biomarker }\end{array}$ & $\begin{array}{l}\text { Tissue, Urine, } \\
\text { Cell lines }\end{array}$ & {$[20,153]$} \\
\hline miR-1224-3p & $\begin{array}{l}\text { Hypermethylation of } \mathrm{CpG} \\
\text { shore }>\text { CGI }\end{array}$ & $3 q 27.1$ & - & $\begin{array}{l}\text { Inhibiting cell } \\
\text { growth }\end{array}$ & $\downarrow$ & $\begin{array}{l}\text { Related to } \\
\text { metastasis and } \\
\text { poor prognosis }\end{array}$ & Tissue & {$[74]$} \\
\hline miR-152 & CGI hypermethylation & $17 \mathrm{q} 21.32$ & & $\begin{array}{l}\text { Inhibiting cell } \\
\text { growth }\end{array}$ & $\downarrow$ & $\begin{array}{l}\text { Potential } \\
\text { biomarker }\end{array}$ & Tissue & {$[74,189]$} \\
\hline $\mathrm{miR}-200 \mathrm{a} / \mathrm{b}$ & 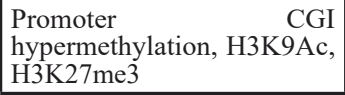 & $1 \mathrm{p} 36.33$ & ZEB1/ZEB2 & Regulating EMT & $\downarrow$ & $\begin{array}{l}\text { Predicting } \\
\text { prognosis }\end{array}$ & Cell lines & {$[186,189]$} \\
\hline $\operatorname{miR}-200 \mathrm{c}$ & $\begin{array}{l}\text { Promoter } \\
\text { hypermethylation, H3K9Ac, } \\
\text { H3K27me3 }\end{array}$ & $12 \mathrm{p} 13.31$ & ZEB1/ZEB2 & Regulating EMT & $\downarrow$ & $\begin{array}{l}\text { Associated with } \\
\text { progression of } \mathrm{T} 1 \\
\text { stage tumor }\end{array}$ & Cell lines & {$[186]$} \\
\hline miR-205 & $\begin{array}{l}\text { Promoter } \\
\text { hypermethylation }\end{array}$ & $1 \mathrm{q} 32.2$ & ZEB1/ZEB2 & Regulating EMT & $\downarrow$ & $\begin{array}{l}\text { Predicting } \\
\text { prognosis }\end{array}$ & Tissue & {$[186]$} \\
\hline miR-10a & Gene hypermethylation & $17 q 21.32$ & - & Unclear & $\downarrow$ & $\begin{array}{l}\text { Potential } \\
\text { biomarker }\end{array}$ & J82 cell lines & [189] \\
\hline miR-193a-3p & Gene hypermethylation & $17 q 11.2$ & $\begin{array}{l}\text { SRSF2/ } \\
\text { PLAU/HIC2 }\end{array}$ & $\begin{array}{l}\text { Related to } \\
\text { chemo-resistance }\end{array}$ & $\downarrow^{*}$ & $\begin{array}{l}\text { Chemo-resistance } \\
\text { due to the } \\
\text { hypermethylation }\end{array}$ & $\begin{array}{l}5637 \text { and } \\
\text { H-bc cell lines }\end{array}$ & {$[190]$} \\
\hline miR-34a & $\begin{array}{l}\text { Promoter } \\
\text { hypermethylation }\end{array}$ & $1 \mathrm{p} 36.22$ & HNF4G & $\begin{array}{l}\text { Tumor } \\
\text { suppressor }\end{array}$ & $\downarrow_{\mathrm{MIBC}}$ in & $\begin{array}{l}\text { Chemo-sensitivity } \\
\text { enhanced by } \\
\text { demethylation }\end{array}$ & $\begin{array}{l}\text { Tissue, } \\
\text { Cell lines }\end{array}$ & {$[72,76]$} \\
\hline $\operatorname{mir}-516 a$ & CGI hypermethylation & $19 q 13.42$ & - & Unclear & Uncelar & $\begin{array}{l}\text { Potential } \\
\text { biomarker }\end{array}$ & $\begin{array}{l}\text { RT112 and RT4 } \\
\text { cell lines }\end{array}$ & {$[74]$} \\
\hline $\operatorname{mir}-517 \mathrm{a}$ & Gene hypermethylation & $19 q 13.42$ & $\begin{array}{l}\text { AREG/ } \\
\text { BCLAF1 }\end{array}$ & $\begin{array}{l}\text { Accelerating } \\
\text { apoptosis }\end{array}$ & $\downarrow$ & $\begin{array}{l}\text { Demethylation } \\
\text { as a potential } \\
\text { treatment }\end{array}$ & $\begin{array}{l}\text { Boy and T24 cell } \\
\text { lines }\end{array}$ & {$[191]$} \\
\hline $\operatorname{miR}-551 \mathrm{a}$ & CGI hypermethylation & $1 \mathrm{p} 36.32$ & - & $\begin{array}{l}\text { Tumor } \\
\text { suppressor }\end{array}$ & Uncelar & $\begin{array}{l}\text { Potential } \\
\text { biomarker }\end{array}$ & $\begin{array}{l}\text { RT112 and RT4 } \\
\text { cell lines }\end{array}$ & {$[74]$} \\
\hline $\operatorname{miR}-126$ & $\begin{array}{l}\text { Host gene EGFL7 is } \\
\text { regulated by HM }\end{array}$ & $9 \mathrm{q} 34.3$ & ADAM9 & $\begin{array}{l}\text { Tumor } \\
\text { suppressor }\end{array}$ & $\downarrow$ & $\begin{array}{l}\text { New anti-cancer } \\
\text { mechanism } \\
\text { of epigenetic } \\
\text { medicines }\end{array}$ & $\begin{array}{l}\text { Tissue, } \\
\text { T24 cell lines }\end{array}$ & {$[66,192]$} \\
\hline miR-127 & $\begin{array}{l}\text { CGI hypermethylation, } \\
\text { Histone deacetylation }\end{array}$ & $14 q 32.31$ & BCL6 & $\begin{array}{l}\text { Tumor } \\
\text { suppressor }\end{array}$ & $\downarrow$ & $\begin{array}{l}\text { Demethylation } \\
\text { and deacetylation } \\
\text { as potential } \\
\text { therapies }\end{array}$ & $\begin{array}{l}\text { Tissue, } \\
\text { T24 cell lines }\end{array}$ & {$[56]$} \\
\hline miR-99a & $\begin{array}{l}\text { Long range epigenetic } \\
\text { regulation }\end{array}$ & $21 \mathrm{q} 21.1$ & FGFR3 & $\begin{array}{l}\text { Inhibiting cell } \\
\text { proliferation, } \\
\text { migration and } \\
\text { invasion }\end{array}$ & $\begin{array}{l}\downarrow \\
\text { low- in } \\
\text { grade } \\
\text { NMIBC }\end{array}$ & $\begin{array}{l}\text { Specifically } \\
\text { characterizing } \\
\text { low-grade tumor }\end{array}$ & $\begin{array}{l}\text { Tissue, T24 and } \\
\text { EJ Cell lines }\end{array}$ & {$[18,193]$} \\
\hline miR-100 & $\begin{array}{l}\text { Long range epigenetic } \\
\text { regulation }\end{array}$ & $11 \mathrm{q} 24.1$ & FGFR3 & $\begin{array}{l}\text { Decreasing cell } \\
\text { viability in } 3-\mathrm{D} \\
\text { growth }\end{array}$ & $\begin{array}{l}\downarrow \\
\text { low- in } \\
\text { grade } \\
\text { NMIBC }\end{array}$ & $\begin{array}{l}\text { Specifically } \\
\text { characterizing } \\
\text { low-grade tumor }\end{array}$ & $\begin{array}{l}\text { Tissue, RT4 cell } \\
\text { lines }\end{array}$ & {$[18,194]$} \\
\hline
\end{tabular}

HM, histone modifications; CGI, CpG Island; H3K9Ac, H3 lysine 9 acetylation; H3K27me3, H3 lysine 27 trimethylation; EMT, epithelial-mesenchymal transition; MIBC, muscle invasive bladder cancer; NMIBC, non- muscle invasive bladder cancer.

*Downregulated in chemo-sensitive bladder cancer cell lines but overexpressed in chemo-resistant cell lines. 
performed. Thus, more in-depth studies are needed to determine how different types of genetic variations alter the expression of BCa-related miRNAs and what their biological significance is.

\section{Transcription factors}

In addition to the gene variations, numerous transcription factors inside the nucleus would influence miRNA gene transcription. One of the most convincing pieces of evidence is that $\mathrm{NF}-\kappa \mathrm{B}$ can enhance the expression of miR-130b. In bladder cancer, the nuclear

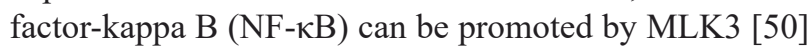
and is shown to induce the expression of miR-130b, an oncogenic miRNA, by directly binding to the promoter region of the miR-130b gene [51]. In addition, Snail-1, which is regulated by the Akt/GSK-3 $\beta$ pathway in $\mathrm{BCa}$, can transcriptionally promote the expression of miR-21 and miR-29 [52, 53]. Some other popular transcription factors are also reported to alter the expression of different miRNAs through the regulation of their transcription (Table 2). Interestingly, most of those miRNAs play an oncogenic role in bladder cancer, which indicates that the regulation by transcription factors could be an important part of the oncogenic miRNA biogenesis pathway and may be relevant to bladder tumourigenesis.

\section{Epigenetic modifications}

Epigenetic modifications of miRNA genes have become a research hotspot in recent years. Although individual miRNAs may be either downregulated or overexpressed, depending on their function, previous research still shows that the overall miRNA expression level is reduced in tumours [54]. Despite our vague understanding of this phenomenon, scientists still believe that epigenetic modifications, including DNA hypermethylation and histone modification, play a key role [55-57]. In bladder cancer, miRNA silencing caused by epigenetic modifications has been widely recognized. Takashi et al. use 5-aza-dC to demethylate two bladder cancer cell lines and find that up to 146 silenced miRNAs are upregulated after the treatment. An additional study shows that in comparison to normal bladder tissues, the methylation level of miRNA genes in bladder cancer tissues is significantly upregulated (>15\%) [20]. The expression of miR-137, an important bladder cancer suppressor [58], is negatively correlated with its methylation in bladder tumour tissue specimens, which indicates that bladder tumourigenesis may be associated with the silence of miRNAs caused by DNA hypermethylation [20]. To gain a better understanding of the epigenetic regulations in $\mathrm{BCa}$, we list the major miRNAs for which the expressions are reportedly regulated via epigenetic modifications in Table 3.

From above knowledge about the epigenetic regulations of miRNA genes, we can see that it is the epigenetic modifications of the anti-cancer miRNAs, especially DNA hypermethylation, that inhibit the formation of primary transcripts and further induce bladder tumourigenesis. However, miRNAs may conversely adjust the core components of the epigenetic modification process. Various BCa-related miRNAs, such as miR-148a, miR-143 and miR-101, are found to have a function in inhibiting DNA methyltransferase (DNMTs) $[59,60]$ and EZH2 (Histone H3K9 methyltransferase) [61, $62]$ and are thus, to some extent, involved in epigenetic modifications. The interactions between miRNA and epigenetic modifications can be summarized as a feedback loop (Figure 3), which is a fundamental mechanism of the disorder in the miRNA biogenesis of bladder cancer.

\section{Host genes}

MiRNAs can be divided into two groups, intergenic miRNAs and intragenic miRNAs, according to their genomic localizations. Intergenic miRNAs are considered as independent transcriptional units while intragenic miRNAs are embedded in other genes; those genes are known as the host genes for the miRNAs [63]. The transcription of intragenic miRNAs is in parallel with their host genes [64]. In bladder cancer, the transcription of some miRNAs is dysregulated due to the changes in their host genes. MiR-205 is located within the LOC642587 gene, which is known as miR-205HG (miR-205 host gene). MiR-205 and miR-205HG share the same gene promoter. $\triangle \mathrm{Np} 63 \alpha$ (an isoform of $\mathrm{p} 63$ ) can bind to a highly conserved region upstream of the miR-205 start site and increase the transcription of both miR-205HG and miR-205 in bladder cancer cell lines. The knockdown of $\triangle \mathrm{Np} 63 \alpha$ in BCa cell lines directly attenuates the binding of RNA Pol II to the miR-205HG promoter and reduces the transcription of both miR-205 and miR-205HG [65]. In addition, EGFL7 is the host gene of miR-126 in bladder cancer tissue and cell lines. The downregulation of miR126 in $\mathrm{BCa}$ is caused by histone modifications of EGFL7 [66]. The above research shows that the upregulation or downregulation of miRNAs transcription in bladder cancer could be modulated indirectly, namely via the host genes.

\section{Disorder of miRNA transcript processing in bladder cancer}

As mentioned above, the pri-miRNA is cleaved by the Microprocessor complex into pre-miRNA. A malfunction at this step would also participate in the aberration of miRNAs and bladder carcinogenesis. One of the most important studies is about the star molecule, p53. TP53 is a vital tumour-suppressor gene whose mutations are deeply embedded in the tumourigenesis of almost all types of malignancies, including bladder cancer. To put it briefly, p53 protein is coded by the TP53 gene, which works to protect cells from the carcinogenesis induced by the accumulation of oncogene mutations [67]. In urinary bladder carcinoma, the disorder of the TP53 gene and its downstream pathways are usually related to muscle 


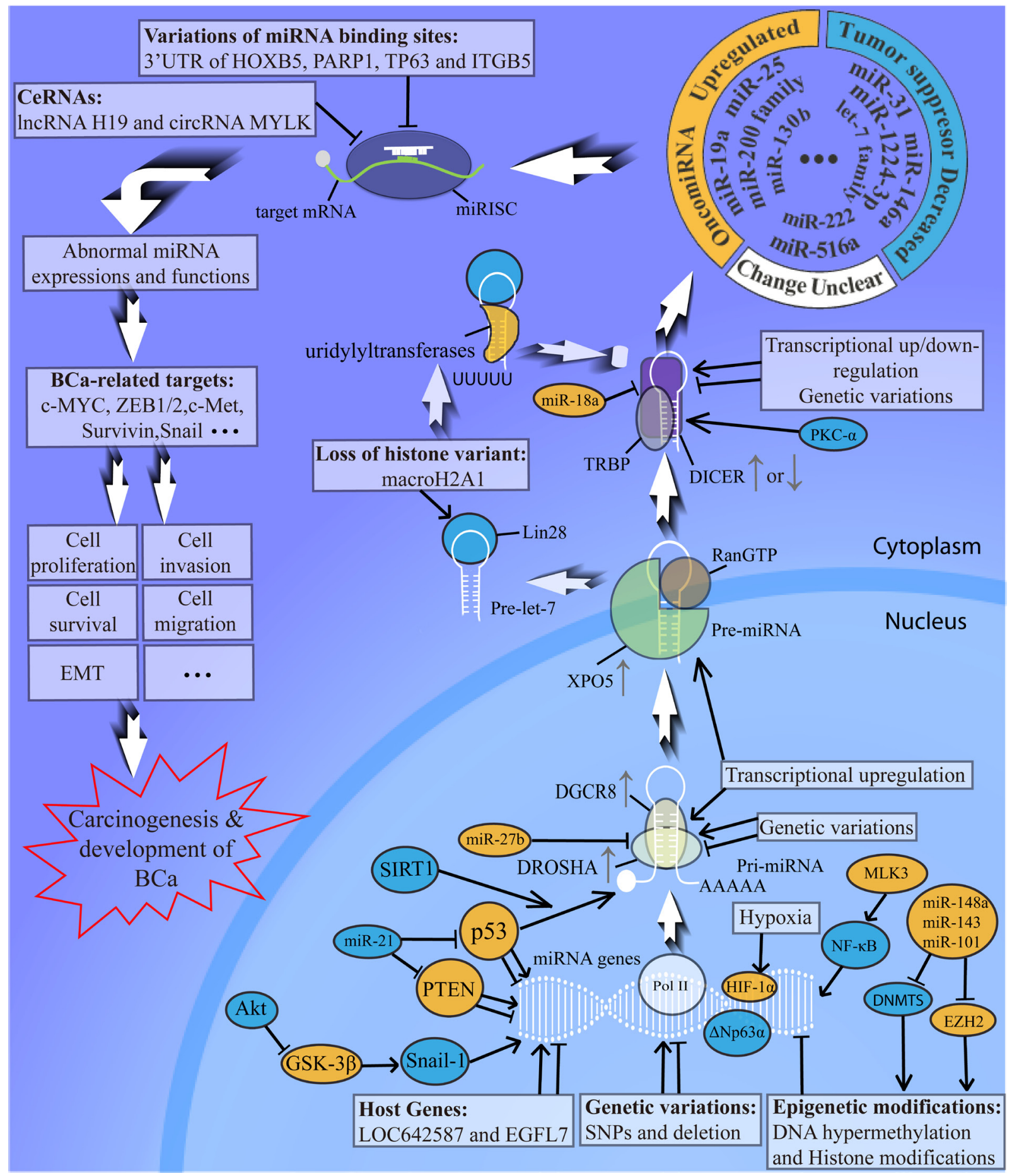

Figure 4: Abnormal miRNA biogenesis in bladder cancer development. Abnormalities of miRNA biogenesis in BCa appear at multiple levels of the whole procedure. Genetic variations, epigenetic modifications, different transcription factors, the host genes as well as hypoxia alter the transcriptions of pri-miRNA; With the help of SIRT1, p53 accelerates the processing of pri-miRNAs (like pri-miR-34a); Microprocessor Complex and XPO5, which are transcriptionally upregulated, lead to wide aberrance of miRNAs in BCa; PKC- $\alpha$, miR-18a and genetic variations induce the dysregulation of DICER and the transcriptional dysregulation of DICER will affect pre-miRNA cleavage in $\mathrm{BCa}$; Loss of macroH2A1 in bladder cancer promote Lin28 to selectively bind to pre-let-7 so that pre-let-7 won't be processed by DICER; The abnormalities at different steps cause the upregulation of oncomiRNAs and the downregulation of tumor suppressors, but the changes of some miRNAs in BCa are still unclear; The variations of miRNA binding sites and ceRNAs lead to malfunction of miRNAs by inhibiting the miRNA-mRNA combination in bladder cancer; Abnormal miRNA expression and function modulate the downstream targets and signaling pathways and eventually lead to carcinogenesis and development of bladder cancer. PTEN, phosphate and tension homology deleted on chromosome ten; Akt, serine/threonine kinase; MLK3, mixed lineage kinase 3; PKC- $\alpha$, protein kinase C- $\alpha$; SIRT-1, Sirtuin-1; ZEB1/2, zinc finger e-box binding homeobox $1 / 2$. 
invasion, higher stage metastasis, and recurrence as well as poor prognosis $[68,69]$. In addition, p53 has been shown to be a key factor in regulating the miRNA biogenesis pathway. The processing of pri-miR-34a has been shown to be promoted by p53 with the help of SIRT1. p53 can interact with DROSHA, thereby promoting the anti-cancer pri-miRNAs to convert into pre-miRNAs [70, 71]. This p53/miR-34a axis also has significant functions in bladder carcinogenesis, such as inhibiting invasion, decreasing recurrence, preventing metastasis and anti-angiogenesis [72-74]. After polyphenol treatment, the proliferation of bladder cancer cells is inhibited by enhancing the function of the p53/miR-34a axis [75]. This result is consistent with what occurs in bladder cells after cisplatin treatment [76], which suggests that different drugs may repair the impaired miRNA biogenesis pathway in bladder cancer cells to some extent by enhancing the expression of p53mediated miRNAs.

The disorder of pri-miRNA processing caused by the aberration of the Microprocessor complex (DROSHA/ DGCR8) will be discussed separately in the text that follows.

\section{Defective maturation of BCa-related miRNAs}

After the synthesis of precursor miRNAs, the RNAs are further processed to generate mature molecules. As a matter of course, the defects at this step result in changes in the BCa-related miRNA expression. The let-7 family, which is known as a group of tumour suppressor miRNAs, could prevent tumourigenesis and cancer development by suppressing the expression of oncogenes and controlling the cell cycle $[77,78]$. In bladder cancer, gefitinib exerts its anti-cancer effect by upregulating let-7 [79]. The expression of let- 7 is regulated by $\operatorname{Lin} 28$ protein, and the interaction of the two proteins forms a regulatory circuit $[80,81]$. Other researchers have noted that the overexpression of Lin28 A or B in human tumours is correlated with the downregulation of let-7 and may be associated with poor prognosis and decreased survival rate in cancer patients $[82,83]$. The studies mentioned above indicate that the Lin 28 protein is involved in carcinogenesis and the clinical processes of cancer due to its inhibiting effect on the expression of let-7. In urinary bladder cancer, Lin28 can prohibit the conversion from pre-let-7 to mature let-7. $\mathrm{Li}$ et al. found that with the over-expression of Lin 28 , the pre-let-7a in bladder tumour tissues is correspondingly upregulated, with a significant downregulation of mature let-7a [84]. Moreover, the expression level of pre-let$7 \mathrm{a}$ is inversely associated with the pathological grades of urothelial carcinoma, which demonstrates a probable way in which the defective maturation of pre-miRNAs influences the pathological features of bladder cancer. Park et al. discover that in bladder cancer cells, the loss of the histone variant, macroH2A1, can significantly suppress the expression of mature let-7 via the upregulation of Lin
28 [85]. This result reconfirms what Lin et al. found in their study. According to a study by Thornton et al., Lin 28 inhibits the formation of mature let-7a by binding to the terminal loop region of pre-let-7a so that the Dicer enzyme could not further process it, and finally, the precursor miRNA would be degraded [80]. Once Lin28 was bound to pre-let-7a, it could recruit uridylyltransferases to add an oligouridine tail to pre-let-7, which could then prevent pre-let-7 from being subjected to DICER processing [86].

In other words, the defective maturation of pre-let7a would directly induce the low expression of let-7a and therefore cause the abnormal differentiation of bladder urothelial cells. Apart from let-7a, however, limited miRNAs are reported in bladder cancer to be dysregulated at the "precursor to mature molecule" level. Hence, future studies about the molecular mechanisms of bladder tumours may focus on the aberrant maturation of different pre-miRNAs and on their interaction with various proteins.

\section{Core components of miRNA biogenesis machinery in the context of bladder cancer}

Multiple proteins participate in the miRNA biogenesis network, among which the Microprocessor (DROSHA/DGCR8), XPO5 and DICER are widely studied. The different roles of these components are shown in Figure 1. If the biological processing of miRNAs is compared to a production line, those proteins would become miRNA biogenesis machinery, whose dysregulation and malfunction will profoundly alter the output of the products-miRNAs and further play a role in bladder tumourigenesis and cancer progression.

\section{Microprocessor complex}

DROSHA and DGCR8 make up the Microprocessor complex of miRNA biogenesis and can process primary miRNAs into precursor miRNAs $[87,88]$. Studies reveal that the aberrant expression of DROSHA is closely related to carcinogenesis because of the significant variations that it causes in miRNA expression [89]. This aberrance will promote the proliferation, metastasis and invasion of tumour cells, thus eventually accelerating the clinical progression of cancer [90]. In bladder tumour tissue specimens from clinical patients, a remarkable increase in expression is observed in both the DROSHA protein and its mRNA. The over-expression of DROSHA is then shown to be associated with poor bladder cancer prognosis [19, 91]. Catto notes that in comparison with healthy controls, the obvious disorder of miRNA expression in patients with bladder cancer is related to the transcriptionally over-expressed DROSHA in bladder tumour tissues [18]. In other words, the upregulation of DROSHA will directly lead to changes in the miRNA expression profile, and, as a result, affect the clinical development of the disease. Besides, the genetic variations in the DROSHA gene may also be a reason for 
its overexpression. An SNP rs10719T $>$ C polymorphism located in the DROSHA gene 3' UTR could regulate the binding activity of miR-27b. The alteration from the $\mathrm{T}$ allele to the $\mathrm{C}$ allele helps the gene to get rid of miR-27b control, leading to the enhanced expression of the DROSHA enzyme and a significantly increased risk of bladder cancer [92]. This research also illustrates that the high expression of DROSHA in bladder cancer and the variation in miRNA expression may involve feedback loop regulation, and they may cooperatively participate in bladder tumourigenesis.

Unlike Lin 28 protein, whose upregulation specifically alters a certain miRNA (let-7), the upregulation of DROSHA is not associated with specific miRNAs. Instead, miRNAs are globally dysregulated due to the over-expression of DROSHA protein in bladder cancer [18]. Perhaps the primary reason is that DROSHA takes part in the common step ("pri-miRNA cleavage") of the biogenesis pathway of each miRNA. Although it is easy to understand that the upregulation of the DROSHA protein can increase the expression of oncogenic miRNAs in bladder cancer, the question as to whether upregulated DROSHA also plays a role in terms of numerous downregulated/silenced miRNAs remains to be answered.

Unlike DROSHA, studies on the changes in DGCR8 in bladder cancer are still very limited. We only know that DGCR8 is also over-expressed in bladder cancer tumour tissues, but it is downregulated in the normal urothelia of patients with bladder cancer [18]. The SNPs in the DGCR8 gene (rs2073778 and rs720012) are associated with the risk of progression and the muscle invasion of NMIBC [93], suggesting that the malfunction of DGCR8 also shows its special clinical significance in bladder cancer.

\section{XPO5}

XPO5 (also known as Exportin 5) works as a transporter to pump pre-miRNA into the cytoplasm [87]. A large scale of dysregulated miRNAs in the normal urothelia of bladder cancer patients is strongly related to the high expression of XPO5 [18], and the XPO5 levels in high grade bladder cancer and invasive bladder cancer are significantly higher than in the levels of low grade and non-invasive bladder cancer. Silencing XPO5 inhibits proliferation and promotes the apoptosis of bladder cancer cells [91]. Similar to the Microprocessor complex, the upregulation of XPO5 also occurs at the transcriptional level [91]. We speculate that the overexpression of XPO5 might accelerate the transportation of tumour-promoting miRNAs to the cytoplasm and therefore alter the expression profile of miRNAs in bladder cancer. More research is needed in terms of the changed miRNA expression caused by the dysregulation of XPO5.

\section{DICER}

DICER is a type of RNAse III enzyme, and it can process the pre-miRNA into a mature duplex [87]. The altered expression level of DICER is reported in various tumours, and its dysregulation is considered to be tightly associated with variations in the miRNA expression profile, which can further mediate carcinogenesis and the poor outcome of malignancies [94, 95]. Confusingly, DICER mRNA and protein have been shown to be upregulated in $\mathrm{BCa}$ only by some researchers, and this upregulation is shown to have close relations to poor clinical prognosis for bladder cancer $[19,91]$. However, for the rest of the studies, totally conflicting results are reported. Those studies reveal low expression for DICER mRNA in bladder cancer tissues $[18,96]$, and this low expression is associated with the more malignant phenotypes of the disease [97]. In BCa, PKC- $\alpha$ is a key factor that modulates the expression of DICER. The reduction of PKC- $\alpha$ can induce lower DICER expression at both the mRNA and protein level and lead to the apoptosis of bladder cancer cells [98]. In contrast to PKC- $\alpha$, the miR-18a in bladder cancer T24 cells can downregulate the transcription of DICER mRNA [99]. A recent study shows that the change of DICER in BCa may alter the miRNA expression and be involved in the development of the disease in that the attenuated DICER expression can induce a decreased level of invasion-associated miRNAs in BCa such as in the miR-200 family, miR-205, miR-31, miR-148a, miR149 and miR-106b and further potentiate the invasion of bladder cancer cells [97]. There is no doubt that the DICER expression change in bladder cancer mediates a variation of the miRNA expression profile and plays a rather important part in the development of this urinary carcinoma. However, the real variation trend for DICER in $\mathrm{BCa}$ and the way in which it works towards the disorder of miRNAs are still unclear.

In addition to the molecules mentioned above, some other important proteins, such as TRBP (that works together with DICER) and AGO (a component of miRISC), are also involved in the miRNA biogenesis machinery (Figure 1). Further studies on the roles of those molecules in the aberrantly expressed miRNAs of bladder cancer will definitely promote a better understanding of this field.

\section{Dysfunction of the miRNA-mRNA binding process in bladder cancer}

It has been confirmed that mature miRNAs target the miRNA-binding sites located in the 3' UTR of the mRNAs [100]. This type of binding is commonly considered as the final step of the whole miRNA biogenesis procedure $[11,21]$. One possible mechanism of the malfunction in the miRNA-mRNA binding process is that the variations in the miRNA binding sites of the target mRNAs disrupt the binding activity so that those mRNAs are set free from the miRNA controls. This mechanism is extensively applicable to miRNAs in bladder cancer. The over- 
expression of the oncogene $\mathrm{HOXB5}$, for instance, can be inhibited by miR-7 in urothelial cells, and SNP 1010A/G is located in the miR-7 binding site of HOXB5 gene. A previous study shows that the existence of the $G$ allele can significantly weaken the binding activity of miR-7 and therefore protect HOXB5 mRNA from the suppression of miR-7. The resulting high expression of HOXB5 leads to higher stages and higher grades of bladder cancer [101]. Similar variations in miRNA binding sites are also reported for the 3'UTR of PARP1, TP63 and ITGB5 mRNA [102-104]. In brief, a large amount of evidence shows that even after the mature miRNAs are produced, the genetic variations on the miRNA binding sites could also impair the function of miRNAs and further have a deep impact on the tumourigenesis and progression of bladder cancer.

Additionally, this focus will soon become a hotspot for miRNA researchers after the concept of competing endogenous RNAs (ceRNAs) is put forward. CeRNAs have a function in inhibiting miRNA-mediated gene silencing [105]. Thus, the dysregulations of miRNAs caused by ceRNAs are also included in the disorders of the final step in the miRNA biogenesis pathway. It is reported that the lncRNA H19 and circRNA MYLK could act as ceRNAs in bladder cancer and bind competitively with miRNA-29a-3p so that the function of mature miRNA$29 a-3 p$ is inhibited [106]. From the available literature, we infer that in bladder cancer, some lncRNAs as well as circRNAs can work as ceRNAs and participate in the regulation of miRNAs on the miRNA-mRNA binding level. The roles that various lncRNAs and circRNAs may play in the dysregulation of miRNAs in bladder cancer would no doubt be a valuable focus of further research.

\section{CONCLUSIONS AND PROSPECTIVE}

In bladder cancer research, numerous miRNAs have been recognized to be aberrantly expressed, and their downstream target genes are partially discussed $[18,24,30]$. In our review, we summarize the latest and most complete expression changes of miRNAs in bladder cancer, and we compare the differences in altered miRNAs among various biological samples. Through our literature review, we show that the cancer-related miRNA expression profiles in tumour tissues, urine and blood samples are all remarkably changed compared to BCa-free people. Variations in miRNA expressions are not identical among these three types of samples (Figure 2). Moreover, our review is the first to outline the dysregulations in the entire miRNA biogenesis process and bladder cancer development at different steps, and the abnormalities of miRNA biogenesis in $\mathrm{BCa}$ development are portrayed in detail in Figure 4. We note that when tracing them to their cause, the altered expressions and malfunctions of miRNAs in bladder cancer are closely related to the abnormalities in one or multiple links or factors of the whole miRNA biogenesis pathway. We also have reasons to believe that the dysregulation of a certain miRNA in bladder cancer is a result of multiple disorders in its biogenesis and functioning procedure. For example, the downregulation of the tumour suppressor miR-34a in tumour tissue samples of $\mathrm{BCa}$ is associated with both epigenetic regulation and the malfunction of the $\mathrm{p} 53$ / miR-34a axis, and it may also be related to the variations in Microprocessor and DICER. Some variations such as epigenetic modifications and the abnormal Microprocessor complex can be conversely regulated by different miRNAs. In conclusion, the abnormal miRNA biogenesis in bladder cancer development might be a key mechanism in the aberrance of miRNA expressions and functions in $\mathrm{BCa}$, and the dysregulated miRNAs will target the downstream signalling pathways such as ZEB1/2 and Survivin; they will eventually have a profound impact on the development of bladder cancer [84, 107-109] (Figure 4).

Due to the urgency of updating the diagnosis methods as well as treating bladder cancer, more investigators are likely to conduct research in the field of BCa-related miRNAs. Accordingly, the altered urine and blood miRNAs may be utilized as specific and noninvasive diagnostic biomarkers. To further illustrate the mechanisms of the abnormal miRNA biogenesis, more detailed and systematic experiments are required. Last but not least, the disorders in the whole miRNA biogenesis procedure may become potential targets for treating urinary bladder carcinoma. Hence, targeting drugs as well as the epigenetic chemicals that could repair the aberrations to some extent may pave the way to new bladder cancer therapies.

\section{ACKNOWLEDGMENTS}

We thank Jo-Mei Lee (West China School of Stomatology, Sichuan University) and Chia-Chen $\mathrm{Lu}$ (Department of Foreign Language and Literature, National Chung Cheng University) for their reading of this manuscript and their suggestions. We also thank American Journal Experts (AJE) for English language editing.

\section{CONFLICTS OF INTEREST}

The authors disclose no potential conflicts of interest.

\section{FUNDING}

This study was supported by the National Natural Science Foundation of China (No. 81472379) and the Leading Talent Project of Shanghai. 


\section{REFERENCES}

1. Ferlay J, Soerjomataram I, Dikshit R, Eser S, Mathers C, Rebelo M, Parkin DM, Forman D and Bray F. Cancer incidence and mortality worldwide: sources, methods and major patterns in GLOBOCAN 2012. International journal of cancer. 2015; 136:E359-386.

2. Pruthi RS, Baldwin N, Bhalani V and Wallen EM. Conservative management of low risk superficial bladder tumors. The Journal of urology. 2008; 179:87-90; discussion 90 .

3. Larre S, Catto JW, Cookson MS, Messing EM, Shariat SF, Soloway MS, Svatek RS, Lotan Y, Zlotta AR and Grossman HB. Screening for bladder cancer: rationale, limitations, whom to target, and perspectives. European urology. 2013; 63:1049-1058.

4. Grosshans H and Filipowicz W. Molecular biology: the expanding world of small RNAs. Nature. 2008; 451:414416.

5. Kutter C and Svoboda P. miRNA, siRNA, piRNA: Knowns of the unknown. RNA biology. 2008; 5:181-188.

6. Bartel DP. MicroRNAs: genomics, biogenesis, mechanism, and function. Cell. 2004; 116:281-297.

7. Song T, Zhang X, Zhang L, Dong J, Cai W, Gao J and Hong B. miR-708 promotes the development of bladder carcinoma via direct repression of Caspase-2. Journal of cancer research and clinical oncology. 2013; 139:11891198.

8. Guo Y, Ying L, Tian Y, Yang P, Zhu Y, Wang Z, Qiu F and Lin J. miR-144 downregulation increases bladder cancer cell proliferation by targeting EZH2 and regulating Wnt signaling. The FEBS journal. 2013; 280:4531-4538.

9. Han Y, Chen J, Zhao X, Liang C, Wang Y, Sun L, Jiang Z, Zhang Z, Yang R, Chen J, Li Z, Tang A, Li X, et al. MicroRNA expression signatures of bladder cancer revealed by deep sequencing. PloS one. 2011; 6:e18286.

10. Tolle A, Jung M, Rabenhorst S, Kilic E, Jung K and Weikert S. Identification of microRNAs in blood and urine as tumour markers for the detection of urinary bladder cancer. Oncology reports. 2013; 30:1949-1956.

11. Tolle A, Ratert N and Jung K. miRNA panels as biomarkers for bladder cancer. Biomarkers in medicine. 2014; 8:733746.

12. Vinall RL, Tepper CG, Ripoll AA, Gandour-Edwards RF, Durbin-Johnson BP, Yap SA, Ghosh PM and deVere White RW. Decreased expression of let-7c is associated with nonresponse of muscle-invasive bladder cancer patients to neoadjuvant chemotherapy. Genes Cancer. 2016; 7:86-97. doi: 10.18632/genesandcancer.103.

13. Cao YH, Zhang HH, Xu HF, Duan YJ, Li Q and Huang B. Prognostic role of microRNA-100 in patients with bladder cancer. Genet Mol Res. 2015; 14:15948-15954.

14. Lin S and Gregory RI. MicroRNA biogenesis pathways in cancer. Nature reviews Cancer. 2015; 15:321-333.
15. Gregory RI, Yan KP, Amuthan G, Chendrimada T, Doratotaj B, Cooch N and Shiekhattar R. The Microprocessor complex mediates the genesis of microRNAs. Nature. 2004; 432:235-240.

16. Park JE, Heo I, Tian Y, Simanshu DK, Chang H, Jee D, Patel DJ and Kim VN. Dicer recognizes the 5' end of RNA for efficient and accurate processing. Nature. 2011; 475:201-205.

17. Ambs S, Prueitt RL, Yi M, Hudson RS, Howe TM, Petrocca F, Wallace TA, Liu CG, Volinia S, Calin GA, Yfantis HG, Stephens RM and Croce CM. Genomic profiling of microRNA and messenger RNA reveals deregulated microRNA expression in prostate cancer. Cancer research. 2008; 68:6162-6170.

18. Catto JW, Miah S, Owen HC, Bryant H, Myers K, Dudziec E, Larre S, Milo M, Rehman I, Rosario DJ, Di Martino E, Knowles MA, Meuth M, et al. Distinct microRNA alterations characterize high- and low-grade bladder cancer. Cancer research. 2009; 69:8472-8481.

19. Zhang Z, Zhang G, Kong C, Bi J, Gong D, Yu X, Shi D, Zhan B and Ye P. EIF2C, Dicer, and Drosha are upregulated along tumor progression and associated with poor prognosis in bladder carcinoma. Tumour biology. 2015; 36:5071-5079.

20. Shimizu T, Suzuki H, Nojima M, Kitamura H, Yamamoto E, Maruyama R, Ashida M, Hatahira T, Kai M, Masumori N, Tokino T, Imai K, Tsukamoto T, et al. Methylation of a panel of microRNA genes is a novel biomarker for detection of bladder cancer. European urology. 2013; 63:1091-1100.

21. Kumar B and Lupold SE. MicroRNA expression and function in prostate cancer: a review of current knowledge and opportunities for discovery. Asian J Androl. 2016; 18:559-567.

22. Tetreault N and De Guire V. miRNAs: their discovery, biogenesis and mechanism of action. Clin Biochem. 2013; 46:842-845.

23. Gottardo F, Liu CG, Ferracin M, Calin GA, Fassan M, Bassi P, Sevignani C, Byrne D, Negrini M, Pagano F, Gomella LG, Croce CM and Baffa R. Micro-RNA profiling in kidney and bladder cancers. Urologic oncology. 2007; 25:387-392.

24. Ichimi T, Enokida H, Okuno Y, Kunimoto R, Chiyomaru T, Kawamoto K, Kawahara K, Toki K, Kawakami K, Nishiyama K, Tsujimoto G, Nakagawa $M$ and Seki $\mathrm{N}$. Identification of novel microRNA targets based on microRNA signatures in bladder cancer. International journal of cancer. 2009; 125:345-352.

25. Cheng Y, Zhang X, Li P, Yang C, Tang J, Deng X, Yang X, Tao J, Lu Q and Li P. MiR-200c promotes bladder cancer cell migration and invasion by directly targeting RECK. Onco Targets Ther. 2016; 9:5091-5099.

26. Zhang HH, Qi F, Cao YH, Zu XB and Chen MF. Expression and clinical significance of microRNA-21, maspin and vascular endothelial growth factor-C in bladder cancer. Oncology letters. 2015; 10:2610-2616. 
27. Li X, Chen J, Hu X, Huang Y, Li Z, Zhou L, Tian Z, Ma H, Wu Z, Chen M, Han Z, Peng Z, Zhao X, et al. Comparative mRNA and microRNA expression profiling of three genitourinary cancers reveals common hallmarks and cancer-specific molecular events. PloS one. 2011; 6:e22570.

28. Song T, Xia W, Shao N, Zhang X, Wang C, Wu Y, Dong J, Cai $\mathrm{W}$ and Li H. Differential miRNA expression profiles in bladder urothelial carcinomas. Asian Pacific journal of cancer prevention. 2010; 11:905-911.

29. Egawa H, Jingushi K, Hirono T, Ueda Y, Kitae K, Nakata W, Fujita K, Uemura M, Nonomura N and Tsujikawa K. The miR-130 family promotes cell migration and invasion in bladder cancer through FAK and Akt phosphorylation by regulating PTEN. Scientific reports. 2016; 6:20574.

30. Wszolek MF, Rieger-Christ KM, Kenney PA, Gould JJ, Silva Neto B, Lavoie AK, Logvinenko T, Libertino JA and Summerhayes IC. A MicroRNA expression profile defining the invasive bladder tumor phenotype. Urologic oncology. 2011; 29:794-801 e791.

31. Mahdavinezhad A, Mousavibahar SH, Poorolajal J, Yadegarazari R, Jafari M, Shabab N and Saidijam M. Association between tissue miR-141, miR-200c and miR$30 \mathrm{~b}$ and bladder cancer: a matched case-control study. Urology journal. 2015; 12:2010-2013.

32. Mahdavinezhad A, Mousavi-Bahar SH, Poorolajal J, Yadegarazari R, Jafari M, Shabab N and Saidijam M. Evaluation of miR-141, miR-200c, miR-30b Expression and Clinicopathological Features of Bladder Cancer. International journal of molecular and cellular medicine. 2015; 4:32-39.

33. Ratert N, Meyer HA, Jung M, Lioudmer P, Mollenkopf HJ, Wagner I, Miller K, Kilic E, Erbersdobler A, Weikert S and Jung K. miRNA profiling identifies candidate mirnas for bladder cancer diagnosis and clinical outcome. The Journal of molecular diagnostics. 2013; 15:695-705.

34. Lin R, Shen W, Zhi Y and Zhou Z. Prognostic value of miR26a and HMGA1 in urothelial bladder cancer. Biomedicine \& pharmacotherapy. 2014; 68:929-934.

35. Lin Y, Chen H, Hu Z, Mao Y, Xu X, Zhu Y, Xu X, Wu J, Li S, Mao Q, Zheng X and Xie L. miR-26a inhibits proliferation and motility in bladder cancer by targeting HMGA1. FEBS letters. 2013; 587:2467-2473.

36. Puerta-Gil P, Garcia-Baquero R, Jia AY, Ocana S, AlvarezMugica M, Alvarez-Ossorio JL, Cordon-Cardo C, Cava F and Sanchez-Carbayo M. miR-143, miR-222, and miR452 are useful as tumor stratification and noninvasive diagnostic biomarkers for bladder cancer. Am J Pathol. 2012; 180:1808-1815.

37. Pignot G, Cizeron-Clairac G, Vacher S, Susini A, Tozlu S, Vieillefond A, Zerbib M, Lidereau R, Debre B, AmsellemOuazana D and Bieche I. microRNA expression profile in a large series of bladder tumors: identification of a 3-miRNA signature associated with aggressiveness of muscle-invasive bladder cancer. International journal of cancer. 2013; 132:2479-2491
38. Sun DK, Wang JM, Zhang P and Wang YQ. MicroRNA-138 Regulates Metastatic Potential of Bladder Cancer Through ZEB2. Cellular physiology and biochemistry. 2015; 37:2366-2374.

39. Long JD, Sullivan TB, Humphrey J, Logvinenko T, Summerhayes KA, Kozinn S, Harty N, Summerhayes IC, Libertino JA, Holway AH and Rieger-Christ KM. A noninvasive miRNA based assay to detect bladder cancer in cell-free urine. American journal of translational research. 2015; 7:2500-2509.

40. Miah S, Dudziec E, Drayton RM, Zlotta AR, Morgan SL, Rosario DJ, Hamdy FC and Catto JW. An evaluation of urinary microRNA reveals a high sensitivity for bladder cancer. British journal of cancer. 2012; 107:123-128.

41. Wang G, Chan ES, Kwan BC, Li PK, Yip SK, Szeto CC and $\mathrm{Ng}$ CF. Expression of microRNAs in the urine of patients with bladder cancer. Clinical genitourinary cancer. 2012; 10:106-113.

42. Lin T, Dong W, Huang J, Pan Q, Fan X, Zhang C and Huang L. MicroRNA-143 as a tumor suppressor for bladder cancer. The Journal of urology. 2009; 181:1372-1380.

43. Saunders MA, Liang $\mathrm{H}$ and $\mathrm{Li}$ WH. Human polymorphism at microRNAs and microRNA target sites. Proc Natl Acad Sci U S A. 2007; 104:3300-3305.

44. Ryan BM, Robles AI and Harris CC. Genetic variation in microRNA networks: the implications for cancer research. Nature reviews Cancer. 2010; 10:389-402.

45. Wang M, Chu H, Li P, Yuan L, Fu G, Ma L, Shi D, Zhong D, Tong N, Qin C, Yin C and Zhang Z. Genetic variants in miRNAs predict bladder cancer risk and recurrence. Cancer research. 2012; 72:6173-6182.

46. Deng Y, Bai H and Hu H. rs11671784 G/A variation in miR-27a decreases chemo-sensitivity of bladder cancer by decreasing miR-27a and increasing the target RUNX1 expression. Biochemical and biophysical research communications. 2015; 458:321-327.

47. Calin GA, Dumitru CD, Shimizu M, Bichi R, Zupo S, Noch E, Aldler H, Rattan S, Keating M, Rai K, Rassenti L, Kipps T, Negrini M, et al. Frequent deletions and down-regulation of micro- RNA genes miR15 and miR16 at 13q14 in chronic lymphocytic leukemia. Proc Natl Acad Sci U S A. 2002; 99:15524-15529.

48. Powers JT, Tsanov KM, Pearson DS, Roels F, Spina CS, Ebright R, Seligson M, de Soysa Y, Cahan P, Theissen J, Tu HC, Han A, Kurek KC, et al. Multiple mechanisms disrupt the let-7 microRNA family in neuroblastoma. Nature. 2016; 535:246-251.

49. Veerla S, Lindgren D, Kvist A, Frigyesi A, Staaf J, Persson H, Liedberg F, Chebil G, Gudjonsson S, Borg A, Mansson W, Rovira C and Hoglund M. MiRNA expression in urothelial carcinomas: important roles of miR-10a, miR222, miR-125b, miR-7 and miR-452 for tumor stage and metastasis, and frequent homozygous losses of miR-31. International journal of cancer. 2009; 124:2236-2242. 
50. Song T, Zhang X, Yang G, Song Y and Cai W. Decrement of miR-199a-5p contributes to the tumorigenesis of bladder urothelial carcinoma by regulating MLK3/NF-kappaB pathway. American journal of translational research. 2015; 7:2786-2794.

51. Cui X, Kong C, Zhu Y, Zeng Y, Zhang Z, Liu X, Zhan B, Piao C and Jiang Z. miR-130b, an onco-miRNA in bladder cancer, is directly regulated by NF-kappaB and sustains NF-kappaB activation by decreasing Cylindromatosis expression. Oncotarget. 2016; 7: 48547-48561. doi: 10.18632/oncotarget.10423.

52. Xu X, Zhu Y, Liang Z, Li S, Xu X, Wang X, Wu J, Hu Z, Meng S, Liu B, Qin J, Xie L and Zheng X. c-Met and CREB1 are involved in miR-433-mediated inhibition of the epithelial-mesenchymal transition in bladder cancer by regulating Akt/GSK-3beta/Snail signaling. Cell death \& disease. 2016; 7:e2088.

53. Musavi Shenas SM, Mansoori B, Mohammadi A, Salehi S, Kaffash B, Talebi B, Babaloo Z, Shanehbandi D and Baradaran B. SiRNA-mediated silencing of Snail-1 induces apoptosis and alters micro RNA expression in human urinary bladder cancer cell line. Artif Cells Nanomed Biotechnol. 2016:1-6.

54. Lu J, Getz G, Miska EA, Alvarez-Saavedra E, Lamb J, Peck D, Sweet-Cordero A, Ebert BL, Mak RH, Ferrando AA, Downing JR, Jacks T, Horvitz HR, et al. MicroRNA expression profiles classify human cancers. Nature. 2005; 435:834-838.

55. Guil S and Esteller M. DNA methylomes, histone codes and miRNAs: tying it all together. Int J Biochem Cell Biol. 2009; 41:87-95.

56. Saito Y, Liang G, Egger G, Friedman JM, Chuang JC, Coetzee GA and Jones PA. Specific activation of microRNA-127 with downregulation of the proto-oncogene BCL 6 by chromatin-modifying drugs in human cancer cells. Cancer cell. 2006; 9:435-443.

57. Suzuki H, Takatsuka S, Akashi H, Yamamoto E, Nojima M, Maruyama R, Kai M, Yamano HO, Sasaki Y, Tokino $\mathrm{T}$, Shinomura $\mathrm{Y}$, Imai $\mathrm{K}$ and Toyota $\mathrm{M}$. Genome-wide profiling of chromatin signatures reveals epigenetic regulation of MicroRNA genes in colorectal cancer. Cancer research. 2011; 71:5646-5658.

58. Xiu Y, Liu Z, Xia S, Jin C, Yin H, Zhao W and Wu Q. MicroRNA-137 upregulation increases bladder cancer cell proliferation and invasion by targeting PAQR3. PloS one. 2014; 9:e109734.

59. Lombard AP, Mooso BA, Libertini SJ, Lim RM, Nakagawa RM, Vidallo KD, Costanzo NC, Ghosh PM and Mudryj M. miR-148a dependent apoptosis of bladder cancer cells is mediated in part by the epigenetic modifier DNMT1. Mol Carcinog. 2016; 55:757-767.

60. Zhang Q, Zhao W, Ye C, Zhuang J, Chang C, Li Y, Huang X, Shen L, Li Y, Cui Y, Song J, Shen B, Eliaz I, et al. Honokiol inhibits bladder tumor growth by suppressing EZH2/miR-143 axis. Oncotarget. 2015; 6:37335-37348. doi: 10.18632/oncotarget.6135.

61. Wang Y, Xiang W, Wang M, Huang T, Xiao X, Wang L, Tao D, Dong L, Zeng F and Jiang G. Methyl jasmonate sensitizes human bladder cancer cells to gambogic acidinduced apoptosis through down-regulation of EZH2 expression by miR-101. Br J Pharmacol. 2014; 171:618635.

62. Martinez-Fernandez M, Rubio C, Segovia C, LopezCalderon FF, Duenas M and Paramio JM. EZH2 in Bladder Cancer, a Promising Therapeutic Target. Int J Mol Sci. 2015; 16:27107-27132.

63. Saini HK, Griffiths-Jones S and Enright AJ. Genomic analysis of human microRNA transcripts. Proc Natl Acad Sci U S A. 2007; 104:17719-17724.

64. Baskerville $\mathrm{S}$ and Bartel DP. Microarray profiling of microRNAs reveals frequent coexpression with neighboring miRNAs and host genes. RNA. 2005; 11:241-247.

65. Tran MN, Choi W, Wszolek MF, Navai N, Lee IL, Nitti G, Wen S, Flores ER, Siefker-Radtke A, Czerniak B, Dinney $\mathrm{C}$, Barton $\mathrm{M}$ and McConkey DJ. The p63 protein isoform DeltaNp63alpha inhibits epithelial-mesenchymal transition in human bladder cancer cells: role of MIR-205. J Biol Chem. 2013; 288:3275-3288.

66. Saito Y, Friedman JM, Chihara Y, Egger G, Chuang JC and Liang G. Epigenetic therapy upregulates the tumor suppressor microRNA-126 and its host gene EGFL7 in human cancer cells. Biochemical and biophysical research communications. 2009; 379:726-731.

67. Lopez I, L PO, Tucci P, Alvarez-Valin F, R AC and Marin M. Different mutation profiles associated to P53 accumulation in colorectal cancer. Gene. 2012; 499:81-87.

68. Mitra AP, Datar RH and Cote RJ. Molecular pathways in invasive bladder cancer: new insights into mechanisms, progression, and target identification. J Clin Oncol. 2006; 24:5552-5564.

69. Bakkar AA, Wallerand H, Radvanyi F, Lahaye JB, Pissard S, Lecerf L, Kouyoumdjian JC, Abbou CC, Pairon JC, Jaurand MC, Thiery JP, Chopin DK and de Medina SG. FGFR3 and TP53 gene mutations define two distinct pathways in urothelial cell carcinoma of the bladder. Cancer research. 2003; 63:8108-8112.

70. Suzuki HI, Yamagata K, Sugimoto K, Iwamoto T, Kato S and Miyazono K. Modulation of microRNA processing by p53. Nature. 2009; 460:529-533.

71. Herbert KJ, Cook AL and Snow ET. SIRT1 modulates miRNA processing defects in p53-mutated human keratinocytes. J Dermatol Sci. 2014; 74:142-149.

72. Sun H, Tian J, Xian W, Xie T and Yang X. miR-34a inhibits proliferation and invasion of bladder cancer cells by targeting orphan nuclear receptor HNF4G. Disease markers. 2015; 2015:879254.

73. Andrew AS, Marsit CJ, Schned AR, Seigne JD, Kelsey KT, Moore JH, Perreard L, Karagas MR and Sempere LF. Expression of tumor suppressive microRNA-34a is 
associated with a reduced risk of bladder cancer recurrence. International journal of cancer. 2015; 137:1158-1166.

74. Dudziec E, Miah S, Choudhry HM, Owen HC, Blizard S, Glover M, Hamdy FC and Catto JW. Hypermethylation of $\mathrm{CpG}$ islands and shores around specific microRNAs and mirtrons is associated with the phenotype and presence of bladder cancer. Clinical cancer research. 2011; 17:12871296.

75. Zhou B, Yi H, Tan J, Wu Y, Liu G and Qiu Z. Antiproliferative effects of polyphenols from pomegranate rind (Punica granatum L.) on EJ bladder cancer cells via regulation of $\mathrm{p} 53 / \mathrm{miR}-34 \mathrm{a}$ axis. Phytotherapy research. 2015; 29:415-422.

76. Li H, Yu G, Shi R, Lang B, Chen X, Xia D, Xiao H, Guo X, Guan W, Ye Z, Xiao W and Xu H. Cisplatin-induced epigenetic activation of miR-34a sensitizes bladder cancer cells to chemotherapy. Molecular cancer. 2014; 13:8.

77. Peter ME. Let-7 and miR-200 microRNAs: guardians against pluripotency and cancer progression. Cell Cycle. 2009; 8:843-852.

78. Barh D, Malhotra R, Ravi B and Sindhurani P. MicroRNA let-7: an emerging next-generation cancer therapeutic. Curr Oncol. 2010; 17:70-80.

79. Lu Y, Liu P, Van den Bergh F, Zellmer V, James M, Wen W, Grubbs CJ, Lubet RA and You M. Modulation of gene expression and cell-cycle signaling pathways by the EGFR inhibitor gefitinib (Iressa) in rat urinary bladder cancer. Cancer Prev Res (Phila). 2012; 5:248-259.

80. Rybak A, Fuchs H, Smirnova L, Brandt C, Pohl EE, Nitsch $\mathrm{R}$ and Wulczyn FG. A feedback loop comprising lin-28 and let-7 controls pre-let-7 maturation during neural stem-cell commitment. Nat Cell Biol. 2008; 10:987-993.

81. Newman MA, Thomson JM and Hammond SM. Lin-28 interaction with the Let-7 precursor loop mediates regulated microRNA processing. RNA. 2008; 14:1539-1549.

82. Viswanathan SR, Powers JT, Einhorn W, Hoshida Y, Ng TL, Toffanin S, O'Sullivan M, Lu J, Phillips LA, Lockhart VL, Shah SP, Tanwar PS, Mermel CH, et al. Lin28 promotes transformation and is associated with advanced human malignancies. Nature genetics. 2009; 41:843-848.

83. Hamano R, Miyata H, Yamasaki M, Sugimura K, Tanaka K, Kurokawa Y, Nakajima K, Takiguchi S, Fujiwara Y, Mori M and Doki Y. High expression of Lin28 is associated with tumour aggressiveness and poor prognosis of patients in oesophagus cancer. British journal of cancer. 2012; 106:1415-1423.

84. Li Y, Liu H, Lai C, Du X, Su Z and Gao S. The Lin28/ let-7a/c-Myc pathway plays a role in non-muscle invasive bladder cancer. Cell and tissue research. 2013; 354:533541.

85. Park SJ, Shim JW, Park HS, Eum DY, Park MT, Mi Yi J, Choi SH, Kim SD, Son TG, Lu W, Kim ND, Yang K and Heo K. MacroH2A1 downregulation enhances the stemlike properties of bladder cancer cells by transactivation of
Lin28B. Oncogene. 2016; 35:1292-1301.

86. Thornton JE, Chang HM, Piskounova E and Gregory RI. Lin28-mediated control of let-7 microRNA expression by alternative TUTases Zcchc11 (TUT4) and Zcchc6 (TUT7). RNA. 2012; 18:1875-1885.

87. Stefani G and Slack FJ. Small non-coding RNAs in animal development. Nat Rev Mol Cell Biol. 2008; 9:219-230.

88. Lee Y, Ahn C, Han J, Choi H, Kim J, Yim J, Lee J, Provost P, Radmark O, Kim S and Kim VN. The nuclear RNase III Drosha initiates microRNA processing. Nature. 2003; 425:415-419.

89. Muralidhar B, Winder D, Murray M, Palmer R, BarbosaMorais N, Saini H, Roberts I, Pett M and Coleman N. Functional evidence that Drosha overexpression in cervical squamous cell carcinoma affects cell phenotype and microRNA profiles. The Journal of pathology. 2011; 224:496-507.

90. Sugito N, Ishiguro H, Kuwabara Y, Kimura M, Mitsui A, Kurehara H, Ando T, Mori R, Takashima N, Ogawa R and Fujii Y. RNASEN regulates cell proliferation and affects survival in esophageal cancer patients. Clinical cancer research. 2006; 12:7322-7328.

91. Han Y, Liu Y, Gui Y and Cai Z. Inducing cell proliferation inhibition and apoptosis via silencing Dicer, Drosha, and Exportin 5 in urothelial carcinoma of the bladder. Journal of surgical oncology. 2013; 107:201-205.

92. Yuan L, Chu H, Wang M, Gu X, Shi D, Ma L, Zhong D, Du M, Li P, Tong N, Fu G, Qin C, Yin C, et al. Genetic variation in DROSHA 3'UTR regulated by hsa-miR-27b is associated with bladder cancer risk. PloS one. 2013; 8:e81524.

93. Ke HL, Chen M, Ye Y, Hildebrandt MA, Wu WJ, Wei H, Huang M, Chang DW, Dinney CP and Wu X. Genetic variations in micro-RNA biogenesis genes and clinical outcomes in non-muscle-invasive bladder cancer. Carcinogenesis. 2013; 34:1006-1011.

94. Banno K, Yanokura M, Iida M, Adachi M, Nakamura K, Nogami Y, Umene K, Masuda K, Kisu I, Nomura H, Kataoka F, Tominaga E and Aoki D. Application of microRNA in diagnosis and treatment of ovarian cancer. Biomed Res Int. 2014; 2014:232817.

95. Puppin C, Durante C, Sponziello M, Verrienti A, Pecce V, Lavarone E, Baldan F, Campese AF, Boichard A, Lacroix L, Russo D, Filetti S and Damante G. Overexpression of genes involved in miRNA biogenesis in medullary thyroid carcinomas with RET mutation. Endocrine. 2014; 47:528536.

96. Wu D, Tao J, Xu B, Li P, Lu Q and Zhang W. Downregulation of Dicer, a component of the microRNA machinery, in bladder cancer. Mol Med Rep. 2012; 5:695699.

97. Lombard AP, Lim RM, Nakagawa RM, Vidallo KD, Libertini SJ, Platero AJ and Mudryj M. Dicer ablation promotes a mesenchymal and invasive phenotype in bladder 
cancer cells. Oncology reports. 2015; 34:1526-1532.

98. Jiang Z, Kong C, Zhang Z, Zhu Y, Zhang Y and Chen X. Reduction of protein kinase $\mathrm{C}$ alpha (PKC-alpha) promote apoptosis via down-regulation of Dicer in bladder cancer. J Cell Mol Med. 2015; 19:1085-1093.

99. Tao J, Wu D, Li P, Xu B, Lu Q and Zhang W. microRNA18a, a member of the oncogenic miR-17-92 cluster, targets Dicer and suppresses cell proliferation in bladder cancer T24 cells. Mol Med Rep. 2012; 5:167-172.

100. Bartel DP. MicroRNAs: target recognition and regulatory functions. Cell. 2009; 136:215-233.

101. Luo J, Cai Q, Wang W, Huang H, Zeng H, He W, Deng W, Yu H, Chan E, Ng CF, Huang J and Lin T. A microRNA-7 binding site polymorphism in HOXB5 leads to differential gene expression in bladder cancer. PloS one. 2012; 7:e40127.

102. Teo MT, Landi D, Taylor CF, Elliott F, Vaslin L, Cox DG, Hall J, Landi S, Bishop DT and Kiltie AE. The role of microRNA-binding site polymorphisms in DNA repair genes as risk factors for bladder cancer and breast cancer and their impact on radiotherapy outcomes. Carcinogenesis. 2012; 33:581-586.

103. Wang M, Du M, Ma L, Chu H, Lv Q, Ye D, Guo J, Gu C, Xia G, Zhu Y, Ding Q, Yuan L, Fu G, et al. A functional variant in TP63 at 3q28 associated with bladder cancer risk by creating an miR-140-5p binding site. International journal of cancer. 2016; 139:65-74.

104. Liu J, Cheng S, Zhang Y, Li H, Huang J and Zhang P. Association between polymorphisms in the integrin gene predicted microRNA binding sites and bladder cancer risk. Int J Clin Exp Med. 2014; 7:4398-4405.

105. Salmena L, Poliseno L, Tay Y, Kats L and Pandolfi PP. A ceRNA hypothesis: the Rosetta Stone of a hidden RNA language? Cell. 2011; 146:353-358.

106. Huang M, Zhong Z, Lv M, Shu J, Tian Q and Chen J. Comprehensive analysis of differentially expressed profiles of lncRNAs and circRNAs with associated co-expression and ceRNA networks in bladder carcinoma. Oncotarget. 2016; 7: 47186-47200. doi: 10.18632/oncotarget.9706.

107. Xue M, Pang H, Li X, Li H, Pan J and Chen W. Long non-coding RNA urothelial cancer-associated 1 promotes bladder cancer cell migration and invasion by way of the hsa-miR-145-ZEB1/2-FSCN1 pathway. Cancer science. 2016; 107:18-27.

108. Yang R, Liu M, Liang H, Guo S, Guo X, Yuan M, Lian H, Yan X, Zhang S, Chen X, Fang F, Guo H and Zhang C. miR-138-5p contributes to cell proliferation and invasion by targeting Survivin in bladder cancer cells. Molecular cancer. 2016; 15:82.

109. Chiyomaru T, Seki N, Inoguchi S, Ishihara T, Mataki H, Matsushita R, Goto Y, Nishikawa R, Tatarano S, Itesako T, Nakagawa $\mathrm{M}$ and Enokida H. Dual regulation of receptor tyrosine kinase genes EGFR and c-Met by the tumorsuppressive microRNA-23b/27b cluster in bladder cancer.
International journal of oncology. 2015; 46:487-496.

110. Wang G, Zhang H, He H, Tong W, Wang B, Liao G, Chen $\mathrm{Z}$ and $\mathrm{Du} \mathrm{C}$. Up-regulation of microRNA in bladder tumor tissue is not common. International urology and nephrology. 2010; 42:95-102.

111. Yoshino H, Chiyomaru T, Enokida H, Kawakami K, Tatarano S, Nishiyama K, Nohata N, Seki N and Nakagawa $\mathrm{M}$. The tumour-suppressive function of miR-1 and miR133a targeting TAGLN2 in bladder cancer. British journal of cancer. 2011; 104:808-818.

112. Itesako T, Seki N, Yoshino H, Chiyomaru T, Yamasaki T, Hidaka H, Yonezawa T, Nohata N, Kinoshita T, Nakagawa $\mathrm{M}$ and Enokida $\mathrm{H}$. The microRNA expression signature of bladder cancer by deep sequencing: the functional significance of the miR-195/497 cluster. PloS one. 2014; 9:e84311.

113. Canturk KM, Ozdemir M, Can C, Oner S, Emre R, Aslan H, Cilingir O, Ciftci E, Celayir FM, Aldemir O, Ozen M and Artan S. Investigation of key miRNAs and target genes in bladder cancer using miRNA profiling and bioinformatic tools. Molecular biology reports. 2014; 41:8127-8135.

114. Friedman JM, Liang G, Liu CC, Wolff EM, Tsai YC, Ye $\mathrm{W}$, Zhou $\mathrm{X}$ and Jones PA. The putative tumor suppressor microRNA-101 modulates the cancer epigenome by repressing the polycomb group protein EZH2. Cancer research. 2009; 69:2623-2629.

115. Wei Y, He R, Wu Y, Gan B, Wu P, Qiu X, Lan A, Chen G, Wang Q, Lin X, Chen Y and Mo Z. Comprehensive investigation of aberrant microRNA profiling in bladder cancer tissues. Tumour biology. 2016.

116. Zhang DZ, Lau KM, Chan ES, Wang G, Szeto CC, Wong $\mathrm{K}$, Choy RK and Ng CF. Cell-free urinary microRNA-99a and microRNA-125b are diagnostic markers for the noninvasive screening of bladder cancer. PloS one. 2014; 9:e100793.

117. Du M, Shi D, Yuan L, Li P, Chu H, Qin C, Yin C, Zhang Z and Wang M. Circulating miR-497 and miR-663b in plasma are potential novel biomarkers for bladder cancer. Scientific reports. 2015; 5:10437.

118. Xie D, Shang C, Zhang H, Guo Y and Tong X. Upregulation of miR-9 target $\mathrm{CBX} 7$ to regulate invasion ability of bladder transitional cell carcinoma. Medical science monitor. 2015; 21:225-230.

119. Wang H, Zhang W, Zuo Y, Ding M, Ke C, Yan R, Zhan H, Liu J and Wang J. miR-9 promotes cell proliferation and inhibits apoptosis by targeting LASS2 in bladder cancer. Tumour biology. 2015; 36:9631-9640.

120. Mitash N, Agnihotri S, Mittal B, Tiwari S and Mandhani A. Molecular cystoscopy: Micro-RNAs could be a marker for identifying genotypic changes for transitional cell carcinoma of the urinary bladder. Indian journal of urology. 2016; 32:149-153.

121. Xiao H, Li H, Yu G, Xiao W, Hu J, Tang K, Zeng J, He W, Zeng G, Ye Z and Xu H. MicroRNA-10b promotes 
migration and invasion through KLF4 and HOXD10 in human bladder cancer. Oncology reports. 2014; 31:18321838.

122. Eissa S, Matboli M, Hegazy MG, Kotb YM and Essawy NO. Evaluation of urinary microRNA panel in bladder cancer diagnosis: relation to bilharziasis. Translational research. 2015; 165:731-739.

123. Jiang X, Du L, Wang L, Li J, Liu Y, Zheng G, Qu A, Zhang X, Pan H, Yang Y and Wang C. Serum microRNA expression signatures identified from genome-wide microRNA profiling serve as novel noninvasive biomarkers for diagnosis and recurrence of bladder cancer. International journal of cancer. 2015; 136:854-862.

124. Jiang QQ, Liu B and Yuan T. MicroRNA-16 inhibits bladder cancer proliferation by targeting Cyclin D1. Asian Pacific journal of cancer prevention. 2013; 14:4127-4130.

125. Nagata M, Muto S and Horie S. Molecular Biomarkers in Bladder Cancer: Novel Potential Indicators of Prognosis and Treatment Outcomes. 2016; 2016:8205836.

126. Mengual L, Lozano JJ, Ingelmo-Torres M, Gazquez C, Ribal MJ and Alcaraz A. Using microRNA profiling in urine samples to develop a non-invasive test for bladder cancer. International journal of cancer. 2013; 133:26312641 .

127. Jiang X, Du L, Duan W, Wang R, Yan K, Wang L, Li J, Zheng G, Zhang X, Yang Y and Wang C. Serum microRNA expression signatures as novel noninvasive biomarkers for prediction and prognosis of muscle-invasive bladder cancer. Oncotarget. 2016; 7: 36733-36742. doi: 10.18632/ oncotarget.9166.

128. Feng Y, Liu J, Kang Y, He Y, Liang B, Yang P and Yu Z. miR-19a acts as an oncogenic microRNA and is upregulated in bladder cancer. Journal of experimental \& clinical cancer research. 2014; 33:67.

129. Dyrskjot L, Ostenfeld MS, Bramsen JB, Silahtaroglu AN, Lamy P, Ramanathan R, Fristrup N, Jensen JL, Andersen CL, Zieger K, Kauppinen S, Ulhoi BP, Kjems J, et al. Genomic profiling of microRNAs in bladder cancer: miR129 is associated with poor outcome and promotes cell death in vitro. Cancer research. 2009; 69:4851-4860.

130. Neely LA, Rieger-Christ KM, Neto BS, Eroshkin A, Garver J, Patel S, Phung NA, McLaughlin S, Libertino JA, Whitney D and Summerhayes IC. A microRNA expression ratio defining the invasive phenotype in bladder tumors. Urologic oncology. 2010; 28:39-48.

131. Pence S, Ozbek E, Ozan Tiryakioglu N and Ersoy Tunali N. Deregulation of seven $\mathrm{CpG}$ island-harboring miRNAs in bladder cancer: miR-155 and miR-23b as the most promising oncomiRs. Cellular and molecular biology. 2016; 62:25-30.

132. Armstrong DA, Green BB, Seigne JD, Schned AR and Marsit CJ. MicroRNA molecular profiling from matched tumor and bio-fluids in bladder cancer. Molecular cancer. 2015; 14:194.
133. Majid S, Dar AA, Saini S, Deng G, Chang I, Greene K, Tanaka Y, Dahiya R and Yamamura S. MicroRNA-23b functions as a tumor suppressor by regulating Zeb1 in bladder cancer. PloS one. 2013; 8:e67686.

134. Inoguchi S, Seki N, Chiyomaru T, Ishihara T, Matsushita $\mathrm{R}$, Mataki H, Itesako $\mathrm{T}$, Tatarano S, Yoshino $\mathrm{H}$, Goto Y, Nishikawa R, Nakagawa M and Enokida H. Tumoursuppressive microRNA-24-1 inhibits cancer cell proliferation through targeting FOXM1 in bladder cancer. FEBS letters. 2014; 588:3170-3179.

135. Adam L, Wszolek MF, Liu CG, Jing W, Diao L, Zien A, Zhang JD, Jackson D and Dinney CP. Plasma microRNA profiles for bladder cancer detection. Urologic oncology. 2013; 31:1701-1708.

136. Miyamoto K, Seki N, Matsushita R, Yonemori M, Yoshino $H$, Nakagawa $M$ and Enokida $H$. Tumour-suppressive miRNA-26a-5p and miR-26b-5p inhibit cell aggressiveness by regulating PLOD2 in bladder cancer. British journal of cancer. 2016; 115:354-363.

137. Fan Y, Song X, Du H, Luo C, Wang X, Yang X, Wang Y and $\mathrm{Wu}$ X. Down-regulation of miR-29c in human bladder cancer and the inhibition of proliferation in T24 cell via PI3K-AKT pathway. Medical oncology. 2014; 31:65.

138. Zhao X, Li J, Huang S, Wan X, Luo H and Wu D. MiRNA$29 \mathrm{c}$ regulates cell growth and invasion by targeting CDK6 in bladder cancer. American journal of translational research. 2015; 7:1382-1389.

139. Zhang C, Ma X, Du J, Yao Z, Shi T, Ai Q, Chen X, Zhang Z, Zhang $\mathrm{X}$ and Yao X. MicroRNA-30a as a prognostic factor in urothelial carcinoma of bladder inhibits cellular malignancy by antagonising Notch1. BJU international. 2016; 118:578-589.

140. Pospisilova S, Pazourkova E, Horinek A, Brisuda A, Svobodova I, Soukup V, Hrbacek J, Capoun O, Hanus T, Mares J, Korabecna M and Babjuk M. MicroRNAs in urine supernatant as potential non-invasive markers for bladder cancer detection. Neoplasma. 2016; 63:799-808.

141. Chen YH, Wang SQ, Wu XL, Shen M, Chen ZG, Chen XG, Liu YX, Zhu XL, Guo F, Duan XZ, Han XC and Tao $\mathrm{ZH}$. Characterization of microRNAs expression profiling in one group of Chinese urothelial cell carcinoma identified by Solexa sequencing. Urologic oncology. 2013; 31:219-227.

142. Wang S, Li Q, Wang K, Dai Y, Yang J, Xue S, Han F, Zhang Q, Liu J and $\mathrm{Wu} \mathrm{W}$. Decreased expression of microRNA-31 associates with aggressive tumor progression and poor prognosis in patients with bladder cancer. Clinical \& translational oncology. 2013; 15:849-854.

143. Xu T, Qin L, Zhu Z, Wang X, Liu Y, Fan Y, Zhong S, Wang X, Zhang X, Xia L, Zhang X, Xu C and Shen Z. MicroRNA-31 functions as a tumor suppressor and increases sensitivity to mitomycin-C in urothelial bladder cancer by targeting integrin alpha5. Oncotarget. 2016; 7:27445-27457. doi: 10.18632/oncotarget.8479.

144. Wang W, Li T, Han G, Li Y, Shi LH and Li H. Expression 
and role of miR-34a in bladder cancer. Indian journal of biochemistry \& biophysics. 2013; 50:87-92.

145. Yu G, Yao W, Xiao W, Li H, Xu H and Lang B. MicroRNA-34a functions as an anti-metastatic microRNA and suppresses angiogenesis in bladder cancer by directly targeting CD44. Journal of experimental \& clinical cancer research. 2014; 33:779.

146. Motawi TK, Rizk SM, Ibrahim TM and Ibrahim IA. Circulating microRNAs, miR-92a, miR-100 and miR-143, as non-invasive biomarkers for bladder cancer diagnosis. Cell biochemistry and function. 2016; 34:142-148.

147. Yamada Y, Enokida H, Kojima S, Kawakami K, Chiyomaru T, Tatarano S, Yoshino H, Kawahara K, Nishiyama K, Seki N and Nakagawa M. MiR-96 and miR-183 detection in urine serve as potential tumor markers of urothelial carcinoma: correlation with stage and grade, and comparison with urinary cytology. Cancer science. 2011; 102:522-529.

148. Hu Z, Lin Y, Chen H, Mao Y, Wu J, Zhu Y, Xu X, Xu X, Li S, Zheng $X$ and Xie L. MicroRNA-101 suppresses motility of bladder cancer cells by targeting c-Met. Biochemical and biophysical research communications. 2013; 435:82-87.

149. Zhang H, Qi F, Cao Y, Chen M and Zu X. Down-regulated microRNA-101 in bladder transitional cell carcinoma is associated with poor prognosis. Medical science monitor. 2014; 20:812-817.

150. Zhang ZC, Huang Y, Wang XJ, Wang M and Ma LL. Expression of circulating microRNAs in patients with bladder urothelial carcinoma. [Article in Chinese]. Beijing da xue xue bao Yi xue ban. 2013; 45:532-536.

151. Zhou X, Zhang X, Yang Y, Li Z, Du L, Dong Z, Qu A, Jiang $\mathrm{X}$, Li P and Wang C. Urinary cell-free microRNA$106 \mathrm{~b}$ as a novel biomarker for detection of bladder cancer. Medical oncology. 2014; 31:197.

152. Wang Y, Xing QF, Liu XQ, Guo ZJ, Li CY and Sun G. MiR-122 targets VEGFC in bladder cancer to inhibit tumor growth and angiogenesis. American journal of translational research. 2016; 8:3056-3066.

153. Wang X, Wu Q, Xu B, Wang P, Fan W, Cai Y, Gu X and Meng F. MiR-124 exerts tumor suppressive functions on the cell proliferation, motility and angiogenesis of bladder cancer by fine-tuning UHRF1. The FEBS journal. 2015; 282:4376-4388.

154. Zhang T, Wang J, Zhai X, Li H, Li C and Chang J. MiR-124 retards bladder cancer growth by directly targeting CDK4. Acta biochimica et biophysica Sinica. 2014; 46:1072-1079.

155. Snowdon J, Boag S, Feilotter H, Izard J and Siemens DR. A pilot study of urinary microRNA as a biomarker for urothelial cancer. Canadian Urological Association journal. 2013; 7:28-32.

156. Hanke M, Hoefig K, Merz H, Feller AC, Kausch I, Jocham D, Warnecke JM and Sczakiel G. A robust methodology to study urine microRNA as tumor marker: microRNA-126 and microRNA-182 are related to urinary bladder cancer.
Urologic oncology. 2010; 28:655-661.

157. Yonemori M, Seki N, Yoshino H, Matsushita R, Miyamoto K, Nakagawa M and Enokida H. Dual tumorsuppressors miR-139-5p and miR-139-3p targeting matrix metalloprotease 11 in bladder cancer. Cancer science. 2016; 107:1233-1242.

158. Baffa R, Fassan M, Volinia S, O'Hara B, Liu CG, Palazzo JP, Gardiman M, Rugge M, Gomella LG, Croce CM and Rosenberg A. MicroRNA expression profiling of human metastatic cancers identifies cancer gene targets. The Journal of pathology. 2009; 219:214-221.

159. Avgeris M, Mavridis K, Tokas T, Stravodimos K, Fragoulis EG and Scorilas A. Uncovering the clinical utility of miR-143, miR-145 and miR-224 for predicting the survival of bladder cancer patients following treatment. Carcinogenesis. 2015; 36:528-537.

160. Matsushita R, Seki N, Chiyomaru T, Inoguchi S, Ishihara T, Goto Y, Nishikawa R, Mataki H, Tatarano S, Itesako T, Nakagawa $M$ and Enokida $H$. Tumour-suppressive microRNA-144-5p directly targets CCNE1/2 as potential prognostic markers in bladder cancer. British journal of cancer. 2015; 113:282-289.

161. Yun SJ, Jeong P, Kim WT, Kim TH, Lee YS, Song PH, Choi YH, Kim IY, Moon SK and Kim WJ. Cellfree microRNAs in urine as diagnostic and prognostic biomarkers of bladder cancer. International journal of oncology. 2012; 41:1871-1878.

162. Simonato F, Ventura L, Sartori N, Cappellesso R, Fassan M, Busund LT and Fassina A. Detection of microRNAs in archival cytology urine smears. PloS one. 2013; 8:e57490.

163. Sasaki H, Yoshiike M, Nozawa S, Usuba W, Katsuoka Y, Aida K, Kitajima K, Kudo H, Hoshikawa M, Yoshioka Y, Kosaka N, Ochiya T and Chikaraishi T. Expression Level of Urinary MicroRNA-146a-5p Is Increased in Patients With Bladder Cancer and Decreased in Those After Transurethral Resection. Clinical genitourinary cancer. 2016.

164. Ma L, Xu Z, Xu C and Jiang X. MicroRNA-148a represents an independent prognostic marker in bladder cancer. Tumour biology. 2016; 37:7915-7920.

165. Peng Y, Dong W, Lin TX, Zhong GZ, Liao B, Wang B, Gu P, Huang L, Xie Y, Lu FD, Chen X, Xie WB, He W, et al. MicroRNA-155 promotes bladder cancer growth by repressing the tumor suppressor DMTF1. Oncotarget. 2015; 6:16043-16058. doi: 10.18632/oncotarget.3755.

166. Zhang X, Zhang Y, Liu X, Fang A, Wang J, Yang Y, Wang L, Du L and Wang C. Direct quantitative detection for cell-free miR-155 in urine: a potential role in diagnosis and prognosis for non-muscle invasive bladder cancer. Oncotarget. 2016; 7:3255-3266. doi: 10.18632/ oncotarget.6487.

167. Hirata H, Ueno K, Shahryari V, Tanaka Y, Tabatabai ZL, Hinoda Y and Dahiya R. Oncogenic miRNA-182-5p targets Smad4 and RECK in human bladder cancer. PloS one. 2012; 7:e51056. 
168. Yao K, He L, Gan Y, Zeng Q, Dai Y and Tan J. MiR-186 suppresses the growth and metastasis of bladder cancer by targeting NSBP1. Diagn Pathol. 2015; 10:146.

169. Zhang M, Zhuang Q and Cui L. MiR-194 inhibits cell proliferation and invasion via repression of RAP2B in bladder cancer. Biomedicine \& pharmacotherapy. 2016; 80:268-275.

170. Zhao C, Qi L, Chen M, Liu L, Yan W, Tong S and Zu X. microRNA-195 inhibits cell proliferation in bladder cancer via inhibition of cell division control protein 42 homolog/ signal transducer and activator of transcription-3 signaling. Exp Ther Med. 2015; 10:1103-1108.

171. Fang Z, Dai W, Wang X, Chen W, Shen C, Ye G and Li L. Circulating miR-205: a promising biomarker for the detection and prognosis evaluation of bladder cancer. Tumour biology. 2016; 37:8075-8082.

172. Yang Y, Qu A, Liu J, Wang R, Liu Y, Li G, Duan W, Fang Q, Jiang X, Wang L, Zheng G, Du L, Zhang X, et al. Serum miR-210 Contributes to Tumor Detection, Stage Prediction and Dynamic Surveillance in Patients with Bladder Cancer. PloS one. 2015; 10:e135168.

173. Wang J, Zhang X, Wang L, Dong Z, Du L, Yang Y, Guo Y and Wang C. Downregulation of urinary cell-free microRNA-214 as a diagnostic and prognostic biomarker in bladder cancer. Journal of surgical oncology. 2015; 111:992-999.

174. Tatarano S, Chiyomaru T, Kawakami K, Enokida H, Yoshino H, Hidaka H, Yamasaki T, Kawahara K, Nishiyama K, Seki N and Nakagawa M. miR-218 on the genomic loss region of chromosome $4 \mathrm{p} 15.31$ functions as a tumor suppressor in bladder cancer. International journal of oncology. 2011; 39:13-21.

175. Cheng Y, Yang X, Deng X, Zhang X, Li P, Tao J and Lu Q. MicroRNA-218 inhibits bladder cancer cell proliferation, migration, and invasion by targeting BMI-1. Tumour biology. 2015; 36:8015-8023.

176. Shang C, Zhang H, Guo Y, Hong Y, Liu Y and Xue Y. MiR-320a down-regulation mediates bladder carcinoma invasion by targeting ITGB3. Molecular biology reports. 2014; 41:2521-2527.

177. Wang C, Chen Z, Ge Q, Hu J, Li F, Hu J, Xu H, Ye Z and Li LC. Up-regulation of p21(WAF1/CIP1) by miRNAs and its implications in bladder cancer cells. FEBS letters. 2014; 588:4654-4664.

178. Wu CT, Lin WY, Chang YH, Lin PY, Chen WC and Chen MF. DNMT1-dependent suppression of microRNA424 regulates tumor progression in human bladder cancer. Oncotarget. 2015; 6:24119-24131. doi: 10.18632/ oncotarget. 4431.

179. Zeng T, Peng L, Chao C, Fu B, Wang G, Wang Y and Zhu $\mathrm{X}$. miR-451 inhibits invasion and proliferation of bladder cancer by regulating EMT. Int J Clin Exp Pathol. 2014; 7:7653-7662.

180. Lan G, Yang L, Xie X, Peng L and Wang Y. MicroRNA- 490-5p is a novel tumor suppressor targeting c-FOS in human bladder cancer. Arch Med Sci. 2015; 11:561-569.

181. Li S, Xu X, Xu X, Hu Z, Wu J, Zhu Y, Chen H, Mao Y, Lin Y, Luo J, Zheng X and Xie L. MicroRNA-490-5p inhibits proliferation of bladder cancer by targeting c-Fos. Biochemical and biophysical research communications. 2013; 441:976-981.

182. Zhang Y, Zhang Z, Li Z, Gong D, Zhan B, Man X and Kong C. MicroRNA-497 inhibits the proliferation, migration and invasion of human bladder transitional cell carcinoma cells by targeting E2F3. Oncology reports. 2016; 36:1293-1300.

183. Tatarano S, Chiyomaru T, Kawakami K, Enokida H, Yoshino H, Hidaka H, Nohata N, Yamasaki T, Gotanda T, Tachiwada T, Seki N and Nakagawa M. Novel oncogenic function of mesoderm development candidate 1 and its regulation by MiR-574-3p in bladder cancer cell lines. International journal of oncology. 2012; 40:951-959.

184. Blick C, Ramachandran A, McCormick R, Wigfield S, Cranston D, Catto $\mathrm{J}$ and Harris AL. Identification of a hypoxia-regulated miRNA signature in bladder cancer and a role for miR-145 in hypoxia-dependent apoptosis. British journal of cancer. 2015; 113:634-644.

185. Guancial EA, Bellmunt J, Yeh S, Rosenberg JE and Berman DM. The evolving understanding of microRNA in bladder cancer. Urologic oncology. 2014; 32:41 e31-40.

186. Wiklund ED, Bramsen JB, Hulf T, Dyrskjot L, Ramanathan R, Hansen TB, Villadsen SB, Gao S, Ostenfeld MS, Borre M, Peter ME, Orntoft TF, Kjems J, et al. Coordinated epigenetic repression of the miR-200 family and miR-205 in invasive bladder cancer. International journal of cancer. $2011 ; 128: 1327-1334$.

187. Li Y, Xu Z, Wang K, Wang N and Zhu M. Network analysis of microRNAs, genes and their regulation in human bladder cancer. Biomed Rep. 2013; 1:918-924.

188. Liu Y, Han Y, Zhang H, Nie L, Jiang Z, Fa P, Gui Y and Cai Z. Synthetic miRNA-mowers targeting miR-183-96182 cluster or miR-210 inhibit growth and migration and induce apoptosis in bladder cancer cells. PloS one. 2012; $7: \mathrm{e} 52280$.

189. Kohler CU, Bryk O, Meier S, Lang K, Rozynek P, Bruning $\mathrm{T}$ and Kafferlein HU. Analyses in human urothelial cells identify methylation of miR-152, miR-200b and miR-10a genes as candidate bladder cancer biomarkers. Biochemical and biophysical research communications. 2013; 438:48-53.

190. Lv L, Deng H, Li Y, Zhang C, Liu X, Liu Q, Zhang D, Wang L, Pu Y, Zhang H, He Y, Wang Y, Yu Y, et al. The DNA methylation-regulated miR-193a-3p dictates the multi-chemoresistance of bladder cancer via repression of SRSF2/PLAU/HIC2 expression. Cell death \& disease. 2014; 5:e1402.

191. Yoshitomi T, Kawakami K, Enokida H, Chiyomaru T, Kagara I, Tatarano S, Yoshino H, Arimura H, Nishiyama K, Seki N and Nakagawa M. Restoration of miR-517a expression induces cell apoptosis in bladder cancer cell 
lines. Oncology reports. 2011; 25:1661-1668.

192. Jia AY, Castillo-Martin M, Bonal DM, Sanchez-Carbayo M, Silva JM and Cordon-Cardo C. MicroRNA-126 inhibits invasion in bladder cancer via regulation of ADAM9. British journal of cancer. 2014; 110:2945-2954.

193. Wu D, Zhou Y, Pan H, Zhou J, Fan Y and Qu P. microRNA99a inhibiting cell proliferation, migration and invasion by targeting fibroblast growth factor receptor 3 in bladder cancer. Oncology letters. 2014; 7:1219-1224.

194. Blick C, Ramachandran A, Wigfield S, McCormick R, Jubb A, Buffa FM, Turley H, Knowles MA, Cranston D, Catto $\mathrm{J}$ and Harris AL. Hypoxia regulates FGFR3 expression via HIF-1alpha and miR-100 and contributes to cell survival in non-muscle invasive bladder cancer. British journal of cancer. 2013; 109:50-59. 